\title{
Nuclear Power Plant Technoecosystem: 18 Years of Hydrobiological Observations
}

\author{
Alexander A. Protasov*, Anzhelika A. Sylaieva, \\ Tatyana N. Novoselova, Yuliya F. Gromova, \\ Irina A. Morozovskaya and Tanita I. Stepanova \\ Institute of Hydrobiology of NAS of Ukraine \\ 12 Geroev Stalingrada, Kiev, 04210, Ukraine
}

Received 10.01.2017, received in revised form 20.03.2017, accepted 18.09.2017

Aquatic part of Khmelnitsky Nuclear Power Plant technoecosystem was studied during the periods of operation of one (1998-2001) and two power units (2005-2016). Changes in species composition, as well as abundance and biomass dynamics of phytoplankton, zooplankton, zoobenthos, zooperiphyton, and higher aquatic plants in the cooling pond and channels were found to be related to both technogenic and biogenic factors. The invasion of alien species constantly occurred in the technoecosystem. Thirteen invader species were noted during the period of research. Invasion of Zebra mussel (Dreissena polymorpha) and submerged plant Najas marina prevented regular operation of the system; sponge Eunapius carteri reached mass development. Some invaders appeared for a short period; others naturalized, but did not reach the mass development. The phenomenon of contourization associated with the invasion and the mass development of the powerful filter feeder-Zebra mussel was observed in the ecosystem during the period of research. Signs of contourization (for example, a significant increase of water transparency) were observed already in years 2-3 after the invasion of the clam; significant changes in the pelagic subsystem were observed only in years 5-6. At the time of the invasion of the second dreissenid species (D. bugensis), population of D. polymorpha was in the stage of stabilization at low level of abundance. The assumption of the possible outbreak of D. bugensis abundance during the first years after its invasion was not confirmed. Thus, the successional processes in the technoecosystem are determined not only by technogenic and natural abiotic, but also biotic factors.

Keywords: technoecosystem, cooling pond, phytoplankton, zooplankton, zoobenthos, zooperiphyton, dreissenidae, invaders.

Citation: Protasov A.A., Sylaieva A.A., Novoselova T.N., Gromova Y.F., Morozovskaya I.A., Stepanova T.I. Nuclear Power Plant technoecosystem: 18 years of hydrobiological observations. J. Sib. Fed. Univ. Biol., 2017, 10(4), 459-484. DOI: 10.17516/19971389-0045.

(C) Siberian Federal University. All rights reserved

* Corresponding author E-mail address: labtech-hb@ukr.net 


\title{
Техноэкосистема АЭС:
}

\section{8 лет гидробиологических наблюдений}

\author{
А.А. Протасов, А.А. Силаева, Т.Н. Новоселова, \\ Ю.Ф. Громова, И.А. Морозовская, Т.И. Степанова \\ Институт гидробиологии НАН Украинь \\ Украина, 04210, Киев, пр. Героев Сталинграда, 12
}

Водную часть техноэкосистемь Хмельницкой АЭС исследовали при функционировании одного (1998-2001 г2.) и двух энергоблоков (2005-2016 г2.). Исследования фитопланктона, зоопланктона, зообентоса, зооперифитона, высиих водных растений в водоеме-охладителе и каналах показали, что во всех подсистемах происходили изменения состава и показателей количественного развития, связанные как $c$ техногенными, так и с биотическими факторами. В техноэкосистеме постоянно происходил инвазийный процесс. За период исследований отмечено 13 видов гидробионтов-инвайдеров. Вселение моллюсков дрейссенид (Dreissena polymorpha, затем D. bugensis), а также погруженных растений Najas marina привело к возникновению биопомех, массового развития достигла губка Eunapius carteri. Некоторые инвайдеры встречались непродолжительное время, другие натурализовались, но не достигали массового развития. За период исследований в экосистеме наблюдалось явление контуризации, связанное с вселением и массовым развитием мощного фильтратора дрейссены (D. polymorpha). Признаки контуризации, в частности значительное повышение прозрачности воды, были отмечены на 2-3 год после вселения моллюска, но существенные изменения в пелагической подсистеме появились только на 5-6-й год. К моменту вселения второго вида дрейссенид популяциия D. polyтогpha находилась в состоянии стабилизации на низком уровне обилия. Предположение о возможной вспышке численности D. bugensis в первые годы после ее вселения не подтвердилось. Таким образом, сукиессионные процессы в техноэкосистеме определяются не только техногенными, природными абиотическими, но и биотическими факторами.

Ключевые слова: техноэкосистема, водоем-охладитель, фитопланктон, зоопланктон, зообентос, зооперифитон, дрейссениды, вселенцы.

\section{Введение}

При проектировании и эксплуатации водоемов-охладителей АЭС, всего комплекса циркуляционного и технического водоснабжения электростанций практически не учитывается тот факт, что они представляют собой сложную гидроэкосистему - комплекс множества взаимосвязанных между собой биотических, абиотических и техно- генных элементов. На основе многолетнего опыта изучения гидробиологического режима водоемов-охладителей энергетических станций, различных элементов систем водоснабжения была сформулирована концепция техноэкосистемы. Она представляет собой совокупность биотопов природного и антропогенного характера, их живого населения, объединенных системой прямых и обратных 
связей, изменяющихся в пространстве и во времени (Protasov et al., 2009; Protasov, 2014a).

Очевидно, что необходим постоянный контроль воздействия работы энергетических станций на окружающую среду, в частности на водные экосистемы. Однако становится все более ясной необходимость контроля кроме гидрохимических, гидрофизических, климатических факторов также и биотических, которые могут влиять на надежность эксплуатации систем водоснабжения АЭС или ТЭС. При этом никакой контроль не будет эффективным без знания закономерностей формирования, функционирования, развития во времени техноэкосистем, их биотических компонентов.

Исследования техноэкосистемы Хмельницкой АЭС, ряда фоновых водных объектов проводились в течение многих лет. За этот период произошли значительные изменения: был веден в эксплуатацию второй энергоблок АЭС, произошло вселение моллюсков дрейс- сенид, сначала Dreissena polymorpha Pall., затем D. bugensis Andr. Появилось несколько новых для экосистемы видов высших водных растений. Виды-вселенцы спровоцировали серьезные биотические помехи в работе систем водоснабжения.

Целью данной работы было на основе многолетних наблюдений установить основные закономерности изменений в водных объектах техноэкосистемы АЭС под действием техногенных и биотических факторов.

\section{Материалы и методы}

Водоем-охладитель Хмельницкой АЭС (ХАЭС, рис. 1) расположен на территории западного Полесья Украины (50¹7'28" с.ш., $26^{\circ} 35^{\prime} 41^{\prime \prime}$ в.д.), большая часть зоны ХАЭС относится к бассейну р. Горынь. Водоемохладитель (ВО) представляет собой искусственно созданный водный объект на p. Гнилой Рог, сток которой полностью аккумулируется в ВО (средний многолетний

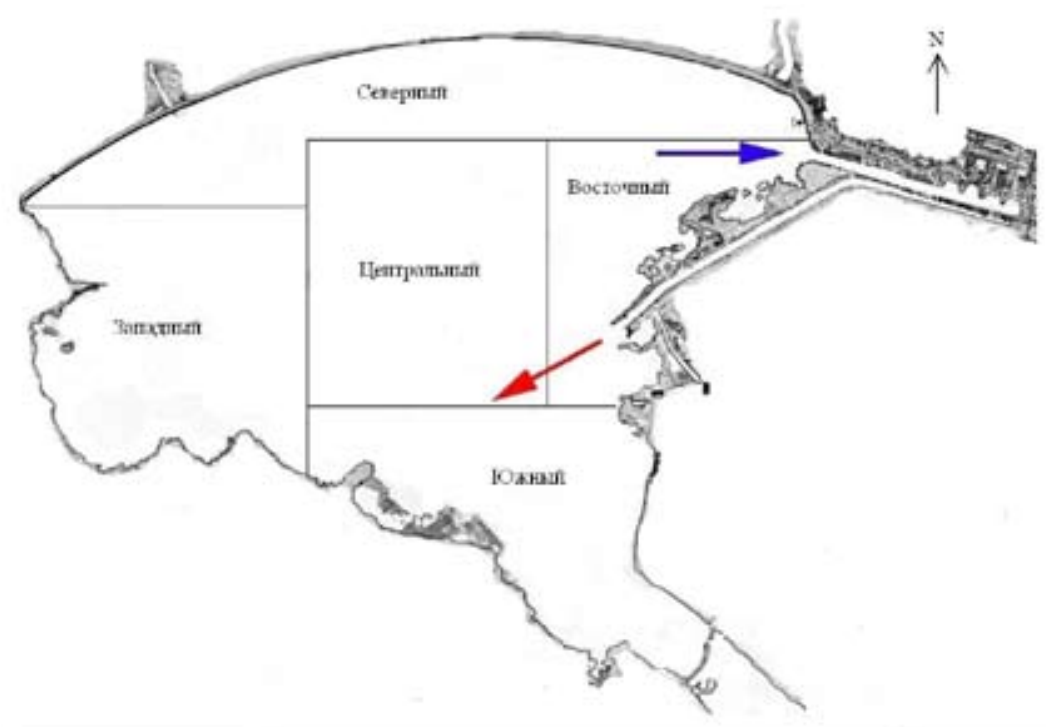

Рис. 1. Схема водоема-охладителя Хмельницкой АЭС. Стрелки указывают направление движения сбросных и охлажденных вод

Fig. 1. Map of Khmelnitsky NPP cooling pond. The arrows indicate the direction of movement of discharge and cooled waters 
сток - 24,12 млн м³ в год). В северной части ВО ограничивает земляная плотина длиной около 7 км, с максимальной высотой 14,7 м, откос со стороны водоема укреплен бетоном. В восточной части водоема расположен подводящий канал (ПК): длина около 1,4 км, ширина по зеркалу около 100 м, глубина $-8,0-9,0$ м, откосы облицованы бетоном. Отводящий канал (ОК) - длина около 3,9 км, глубина около 4 м, ширина около 100 м, на протяжении 700 м от сброса 1-го блока берега облицованы бетоном, далее до выхода в водоем - щебнем, дно укреплено щебнем. В отводящий канал сбрасывается вода из прудов-отстойников очистных сооружений г. Нетешина и промплощадки ХАЭС.

По проектным данным, объем ВО при нормальном подпорном уровне (НПУ) 120 млн м ${ }^{3}$ отметка НПУ - 203,0 м, площадь зеркала при НПУ - 20 км², протяженность береговой линии - 20,4 км. Рельеф ложа отличается неровностью, средняя глубина водоема 6 м, в западной части водоема зафиксированы глубины около 19 м, глубины до 3 м составляют около 40 \% площади акватории. В условиях отсутствия подкачки воды и засушливых периодов в разные сезоны 2007, 2011, 2015 и 2016 гг. в ВО отмечено снижение уровня воды (до 1,6 м в 2016 г.).

Для исследований ВО условно был разделен на пять районов: северный (приплотинный), западный, центральный восточный и южный (рис. 1).

Весь срок гидробиологических исследований и функционирования ХАЭС разделен на три периода. В первый период (1998, 1999, 2001 гг.) условия в водоеме определялись работой единственного энергоблока. Второй этап (2005-2010 гг.) ознаменовался введением в эксплуатацию второго энергоблока (2004 г.), кроме того, незадолго до этого (ориентировочно в 2002-2003 гг.) в ВО спонтанно все- лилась D. polymorpha. Третий этап (с 2012 г. по настоящее время) связан с вселением в ВО второго вида дрейссенид D. bugensis.

Комплексные гидробиологические исследования ВО проводили в основном в летне-осенние периоды и посезонно в 2006 и 2007 гг. Отбор гидробиологических проб осуществляли во всех районах ВО, на участке впадения в ВО р. Гнилой Рог, по всей протяженности подводящего и отводящего каналов и на плотине, в некоторых технических водных объектах ХАЭС.

Для гидрохимических анализов пробы отбирали из поверхностного горизонта, пробы фито- и зоопланктона - из поверхностного, а также определенных глубинных горизонтов батометром Паталаса. Использовали метод «тотального лова», т.е. фильтрации столба воды при подъеме планктонной сети (размер ячеи 80 мкм) с определенной глубины.

$\mathrm{C}$ помощью легководолазного снаряжения шло обследование и отбор проб зооперифитона и зообентоса с поверхности гидросооружений и дна ВО. Отбор проб зооперифитона проводили скребком и коробчатым пробоотборником, зообентоса - дночерпателем СДЧ100 (площадью 0,01 м²), макроформы беспозвоночных на рыхлых субстратах (друзы дрейссены, крупные моллюски-перловицы) отбирали под водой вручную из рамок площадью $0,25 \mathrm{~m}^{2}$ и 0,096 м². Пробы зооперифитона взяты на откосах плотины, подводящего и отводящего каналов, с металлических конструкций в отводящем канале, с камней в южном районе на участке впадения р. Гнилой Рог. Отбор, фиксацию и обработку всех проб проводили по общепринятым методикам (Методи..., 2006), частично задействованы данные и материалы, предоставленные Отделом охраны окружающей среды ХАЭС.

При описании таксономического богатства водорослей и беспозвоночных использо- 
вали термин «НОТ» - низший определённый таксон (Баканов, 1997). Для оценки уровня развития гидробионтов применяли методику оценки водных объектов по гидробиологическим показателям (Методи..., 2006). Названия и систематическая принадлежность таксонов водорослей приведены согласно "AlgaeBase" (www.algaebase.org). Категории и классы качества воды определяли по (Методика..., 1998).

\section{Результаты и обсуждение}

Термический режим ВО определяется погодными условиями и сбросом подогретой воды. В первый период происходило снижение температуры в летний период до уровня естественной при выводе единственного блока в плановый ремонт. При введении в эксплуатацию второго энергоблока максимальные среднегодовые значения температуры возросли от 24,1 до $25,0^{\circ} \mathrm{C}$. Во втором периоде одновременный временный вывод блоков из эксплуатации наблюдался только однажды (июль 2008 г.). Температура воды в ВО была в среднем более чем на $3{ }^{\circ} \mathrm{C}$ выше, чем в природном водном объекте - p. Горынь. В сезонном аспекте следует отметить более значительные различия в температуре в зимний и весенний периоды, чем в летний и осенний.

Прозрачность воды за период исследований изменялась в широком диапазоне (рис. 2). В летне-осенний период в первые годы исследований (1998-2001 гг.) были зарегистрированы относительно низкие значения прозрачности. Во втором периоде наблюдался рост показателей до максимума в 2008 г., с 2010 г. происходило постепенное снижение прозрачности, однако после 2010 г. показатели прозрачности начали возрастать. В многолетнем и сезонном аспекте изменения прозрачности воды в ВО ХАЭС были связаны обратной зависимостью с уровнем биомассы фитопланктона (Протасов, Новоселова, 2015).

Гидрохимический режим. Показатель $\mathrm{pH}$ изменялся в пределах 8,2-8,9, в отдельные периоды превышая 9,0 (2012 г.); более высокими показателями $\mathrm{pH}$ отличался отводящий канал. Концентрация кислорода составляла

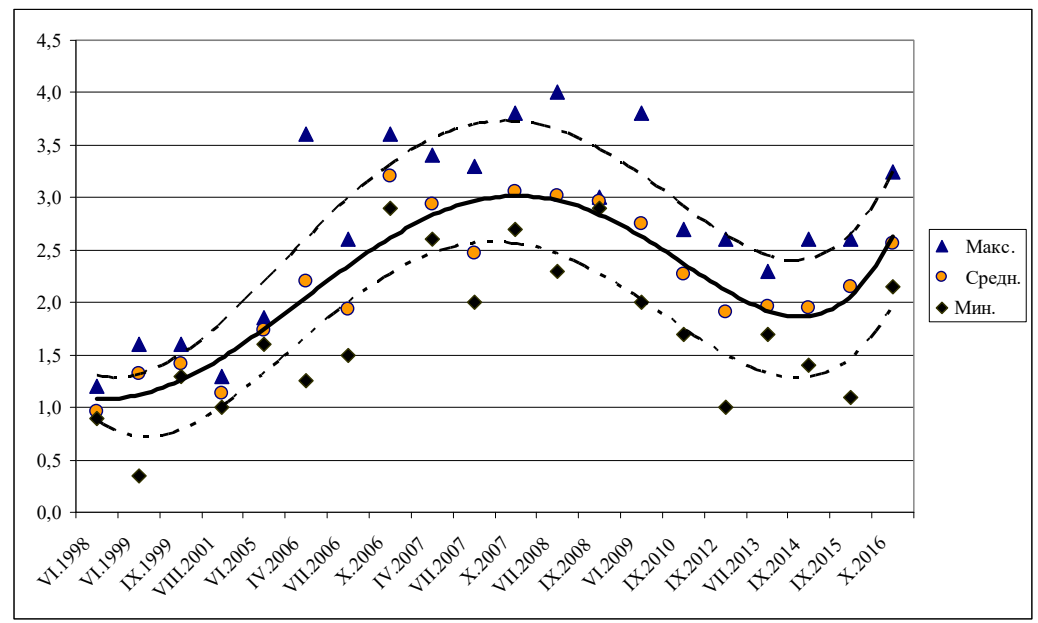

Рис. 2. Прозрачность воды по диску Секки в ВО ХАЭС, весенне-осенние периоды 1998-2016 гг. Сплошная линия - тренд средних значений, пунктирные линии - тренд максимальных и минимальных значений

Fig. 2. Secchi depths in cooling pond of Khmelnitsky NPP, summer-autumn periods of 1998-2016. The solid line is the trend of mean values; the dotted lines are the trends of the maximal and minimal values 
6,1-10,4 мг/дм³, снижаясь до минимальных значений на глубине. Отмечена тенденция уменьшения концентрации ионов кальция, происходящая на фоне увеличения содержания сульфатных ионов. Одной из причин этого, вероятно, был рост биомассы популяции дрейссены. В 2015-2016 гг. наметился процесс возрастания концентрации ионов кальция в воде ВО.

Изменение концентрации главных ионов, а также величины соотношения между ними обусловило постепенное повышение минерализации воды. Например, в июле 2006 г. этот показатель был от 388,89 до 460,94 мг/дм³ по отдельным районам ВО, в 2015 г. средняя минерализация возросла почти до 600 мг/дм³.

В течение всего периода наблюдений отмечалось усиление процесса эвтрофирования водоема-охладителя, что определялось, в первую очередь, возрастанием содержания фосфат-ионов. Это связано не только с внутриводоемными процессами, но и с влиянием внешних поступлений. В водоем поступает в среднем около 500 тыс. м³/месяц сточных вод.

Таксономический состав группировок планктона, бентоса, перифитона - в водоемеохладителе и каналах в период исследований претерпевал существенные изменения.

В период исследований в фитопланктоне пелагической части ВО было обнаружено 395 видов и внутривидовых таксонов водорослей из 8 отделов (8 филумов согласно «AlgaeBase»). Учтены также данные по отводящему и подводящему каналам. Основная часть водорослей (317) была определена до вида. Наиболее широко были представлены Bacillariophyta (142 НОТ) и Chlorophyta (134 НОТ); Суanobacteria были представлены 51, эвгленовые - 21, Streptophyta (Charophyta) 18, Chrysophyta и Xanthophyta (согласно «AlgaeBase» объединены в Ochrophyta) - 17,
Dinophyta (Miozoa) - 9, Cryptophyta - 3 HOT. Следует отметить, что фитопланктон р. Припяти, в бассейне которой находится ВО ХАЭС, и водоемов ее бассейна на уровне отделов обладал подобным флористическим спектром (Мониторинг..., 2003).

В первый период (1998-2001 гг.) богатство водорослей было довольно высоким (в разные годы насчитывалось 73-104 НОТ из 8 отделов) (рис. 3). По отношению к температуре в составе фитопланктона преобладали эвритермные виды и виды с приуроченностью к умеренно теплым водам, однако были отмечены и индикаторы холодных вод: Aulacoseira distans (Ehrenberg) Simonen и Gyrosigma acuminatum (Kützing) Rabenhorst. После введения в эксплуатацию второго блока и вселения в водоем D. polymorpha произошло сокращение количества видов. В 2006-2008 гг. из флористического спектра последовательно выпали представители Cryptophyta, Ochrophyta, Miozoa, Charophyta и Cyanobacteria. Осенью 2008 г. наблюдалось значительное обеднение фитопланктона - до 9 НОТ, из которых 5 были диатомовые, 3 - зеленые, 1 - эвгленовые. Восстановление состава началось в 2009 г. и происходило в обратной последовательности (рис. 3), и в 2012 г. видовой состав на уровне отделов был таким же, как в первом периоде. В летне-осенние периоды 2012-2015 гг. в планктоне насчитывалось 61-115 НОТ водорослей, большей частью зеленых и диатомовых. В видовом спектре были отмечены новые для водоема теплолюбивые цианобактерии Jaaginema geminatum (Schwabe ex Gomont) Anagnostidis \& Komárek, Leptolyngbya fragilis (Gomont) Anagnostidis \& Komárek и диатомовые Staurosira venter (Ehrenberg) Cleve \& J.D. Möller, Planothidium lanceolatum (Brébisson ex Kützing) Lange-Bertalot.

В составе зоопланктона ВО ХАЭС за период с 1998 по 2015 г. обнаружено 120 


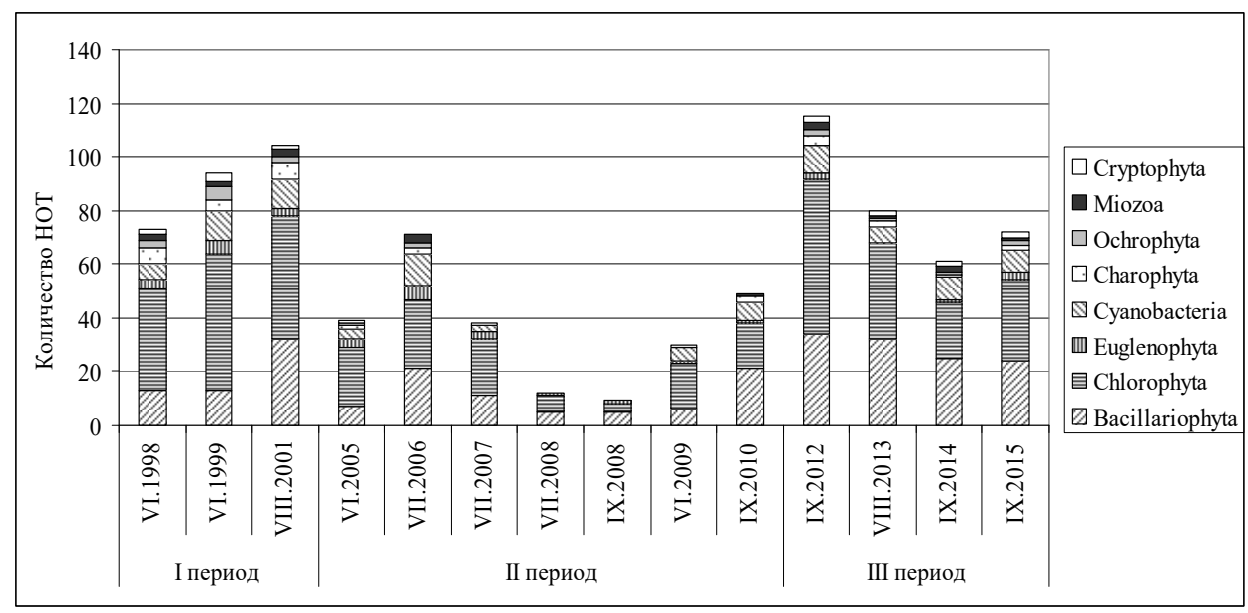

Рис. 3. Таксономическое богатство фитопланктона ВО ХАЭС, летне-осенние периоды 1998-2015 гг.

Fig. 3. Phytoplankton taxonomic richness of Khmelnitsky NPP cooling pond, summer-autumn periods of 1998-2015

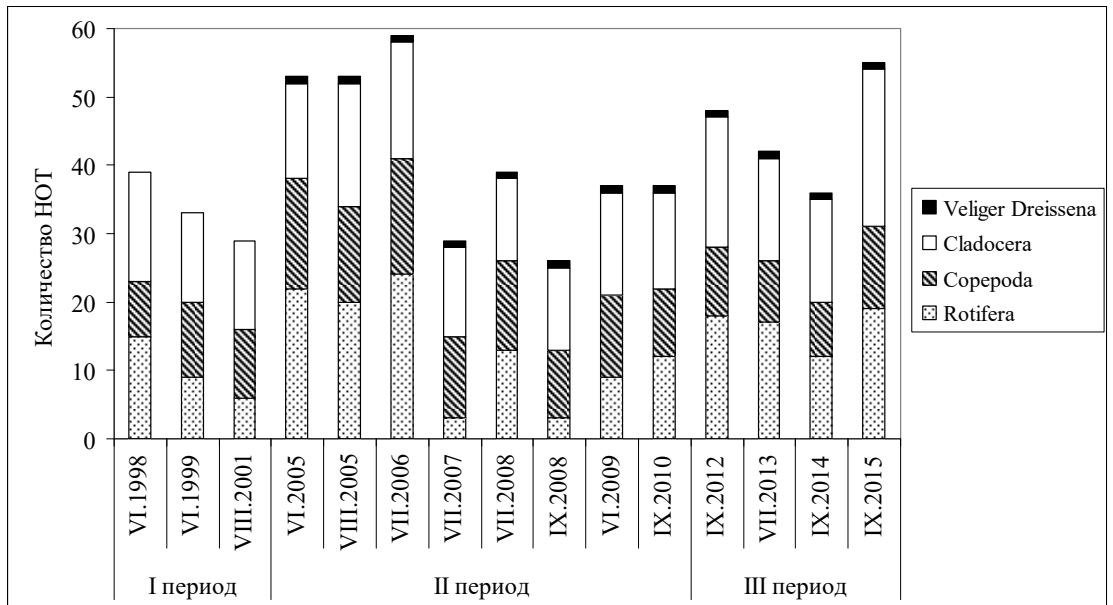

Рис. 4. Таксономическое богатство зоопланктона ВО ХАЭС, летне-осенние периоды 1998-2015 гг.

Fig. 4. Zooplankton taxonomic richness of Khmelnitsky NPP cooling pond, summer-autumn periods of 1998-2015

НОТ (106 идентифицировано до ранга вида), из них Rotifera - 53 (44), Copepoda - 23 (19), Cladocera - 43 (42), также отмечены велигеры Dreissena. Для сравнения, таксономическое богатство в ВО Чернобыльской АЭС (Полесский регион) составляло около 80 видов в доаварийный период и почти $120 \mathrm{HOT} \mathrm{-} \mathrm{в}$ послеаварийный (Protasov, 2006; Pashkova,
2010). В период функционирования одного энергоблока наблюдалось невысокое видовое богатство зоопланктона (рис. 4), количество НОТ было от 29 (2001 г.) до 39 (1998 г.). Во второй период (2005-2006 гг.) видовое богатство увеличилось до 53-59 НОТ. В дальнейшем отмечали общее снижение видового богатства с минимальным значением (26) в 
2008 г. и последующий подъем до 55 НОТ в 2015 г. Самые большие межгодовые изменения были характерны для коловраток. Колебания видового богатства отдельных таксономических групп происходили достаточно синхронно (рис. 4).

Анализ сходства показал, что зоопланктон по составу был наиболее оригинален в 2005-2006 гг. - индекс Смирнова ( $\left.\mathrm{t}_{\mathrm{xx}}\right)$ составлял 122-149, в 2012 г. - 136, 2008 - 116 (в период временной остановки работы станции) и в 2015 г. - 104. Наибольшее сходство состава зоопланктона по индексу Серенсена было характерно для I периода (1998-2001 гг.) 0,67-0,75, начала II периода (2005-2006 гг.) 0,47-0,74 и в период 2008-2015 гг. - 0,43-0,65. В 2007 г. обнаруживались черты сходства как с первым, так и с последующим периодом 2008-2015 гг.

Отмечена тенденция увеличения видового богатства зоопланктона при возрастании средней температуры воды в водоеме до $27{ }^{\circ} \mathrm{C}$, что согласуется с данными по другим ВО (Животова, 2007). Количество НОТ зоопланктона на глубинах от 0 до 5 м чаще всего варьировало незначительно. Однако отмечено, что большее таксономическое богатство коловраток чаще наблюдалось в поверхностных слоях, тогда как вертикальное распределение количества НОТ планктонных ракообразных в целом было более однородным. Таксономическое богатство зоопланктона в литоральной зоне ВО было выше или таким же, как в пелагиали.

В последние годы (2015-2016 гг.) в водоем вселился и массово развивается встречающийся в центральной и южной части Палеарктики и Эфиопской области ветвистоусый рачок Diaphanosoma mongolianum Ueno, заменив обычный до этого D. brachyurum (Liévin), распространенный в основном в бореальных областях.
За весь период наблюдений (все сезоны исследований 1998-2015 гг.) в зообентосе ВО ХАЭС отмечено 162 НОТ беспозвоночных, из них до вида было определено 63 \% (102 вида). В таксономическом отношении зообентос ВО ХАЭС является одним из наиболее богатых среди охладителей АЭС Украины (Протасов, Силаева, 2012). В первый период исследований (при работе одного блока АЭС) в зообентосе обнаружено 87 НОТ (от 30 до 61 НОТ по отдельным сезонам и годам) (Техноэкосистема..., 2011). Во второй период, после вселения D. polymorpha (в 2005-2010 гг.), общее количество НОТ возросло до 128 НОТ (от 42 до 82 НОТ), а в третий - (2012-2015) после вселения D. bugensis - сократилось до 88 HOT (от 42 до 76 НОТ по отдельным годам), т.е. до уровня первого периода (рис. 5). Во втором увеличилось таксономическое богатство пиявок, личинок стрекоз, поденок и ручейников. На распределение видов в группах вселение дрейссены отразилось незначительно, количество групп по годам и сезонам составляло: 11-18 - в первый период, 14-19 - во второй и 13-18 - в третий.

Увеличение количества таксонов до максимальных значений (82 НОТ) отмечено летом 2006 г. (рис. 5), возрастание значений этого показателя в 2015 г., вероятно, связано с дополнительным обследованием мелководий. Так, на мелководьях было отмечено 64, а на остальной акватории ВО - лишь 34 НОТ.

Во все периоды таксономический состав определяли личинки хирономид и олигохеты, составляя соответственно 24-42 и 22-33 \% от общего количества НОТ. Таксономическое разнообразие (индекс Шеннона, рассчитанный по количеству НОТ в группах) мало изменялось на протяжении периода исследований, было невысоким (в среднем по годам около 2), т.е. распределение НОТ по группам было относительно неравномерным. 


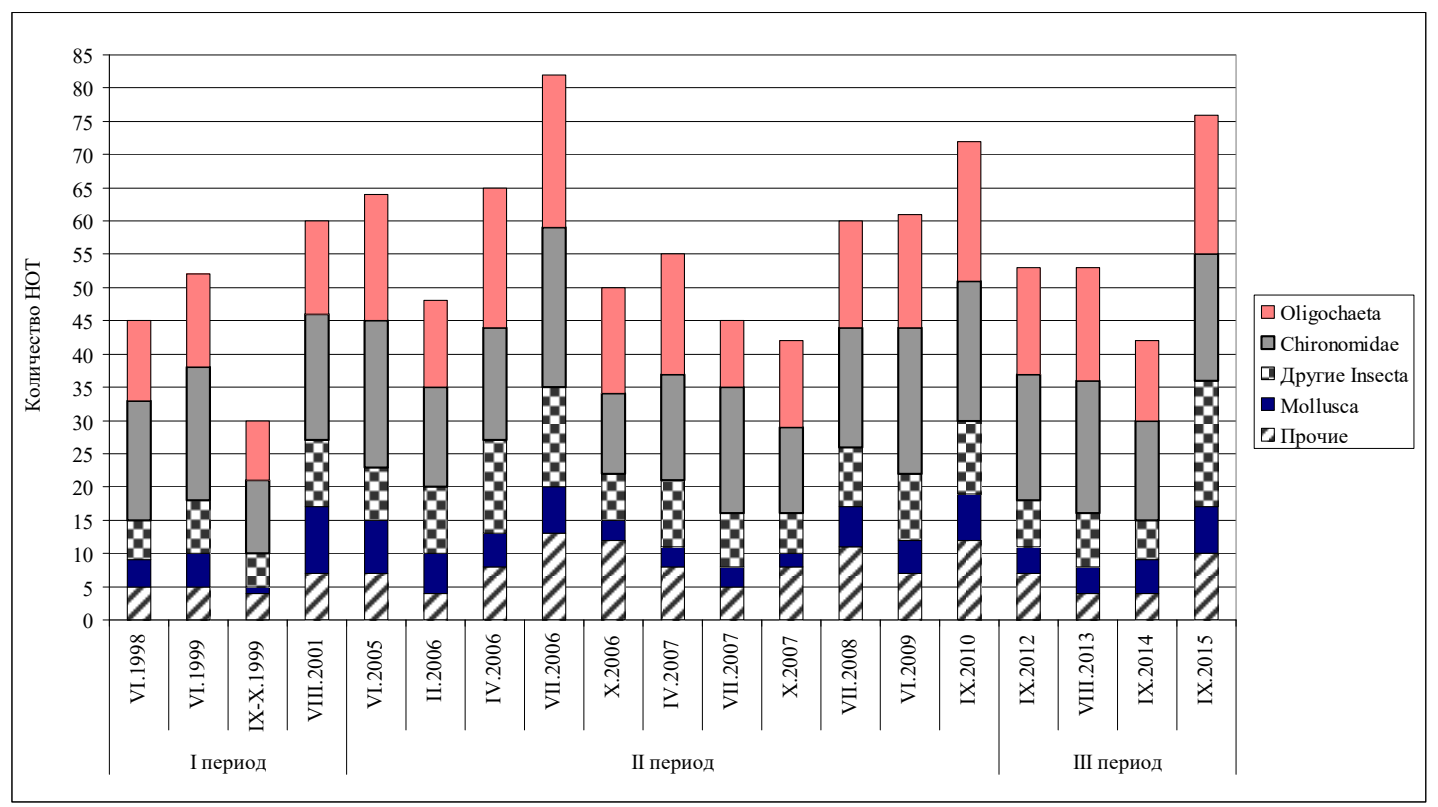

Рис. 5. Таксономическое богатство зообентоса ВО ХАЭС, 1998-2015 гг.; в группу «Другие Insecta» входили группы: Odonata, Ephemeroptera, Heteroptera, Coleoptera, Trichoptera, Ceratopogonidae и прочие Diptera; в группу Mollusca - Dreissena, Bivalvia, Gastrapoda; в группу «Прочие» - Nematoda, Hydra, Hirudinea, Ostracoda, Mysidaceae, Isopoda, Hydracarina, Bryozoa

Fig. 5. Taxonomic richness of zoobenthos of Khmelnitsky NPP cooling pond, 1998-2015; in group «Другие Insecta» were included: Odonata, Ephemeroptera, Heteroptera, Coleoptera, Trichoptera, Ceratopogonidae, and other Diptera; in group Mollusca - Dreissena, Bivalvia, and Gastrapoda; in group «Прочие» - Nematoda, Hydra, Hirudinea, Ostracoda, Mysidaceae, Isopoda, Hydracarina, and Bryozoa

Таксономическое богатство на отдельных станциях было невысоким, в среднем по годам от 7,8 до 21,1 НОТ/станцию. Распределение тех или иных таксонов по акватории было достаточно мозаичным, встречаемостью более 50 \% характеризовались в основном Nematoda, Tubificidae, Ostracoda, Cladotanytarsus mancus Walker, Polypedilum convictum Walker, Procladius ferrugineus Kieffer., большинство же таксонов встречались лишь на отдельных станциях. Встречаемость $D$. polymorpha снижалась на протяжении второго периода, максимальной была в 2005 г. (100\%), минимальной - в 2007 г. (33\%), а в третьем - уменьшалась от 47 до $8 \%$ (2012-2014 гг.). Встречаемость же D. bugensis с момента обнаружения в ВО составляла около $30 \%$.
В пространственном аспекте наиболее бедными в таксономическом отношении были северный и центральный, наиболее богатыми - западный, восточный и южный районы, что определяется, в основном, глубиной и типом грунта.

В отводящем канале, в условиях значительного подогрева, зообентос был представлен обычными таксонами беспозвоночных, наибольшим разнообразием характеризовались личинки хирономид и олигохеты, зарегистрированы также губки, нематоды, ракушковые раки, личинки ручейников, поденок и двукрылых, мшанки, в 2015 г. обнаружены олигохеты сем. Pristinidae (не идентифицированные даже до рода, возможно тропического происхождения). 
Участок впадения р. Гнилой Рог отличался таксономической специфичностью - в отдельные сезоны только здесь встречались планарии, губки, некоторые виды пиявок, олигохеты сем. Naididae, личинки жуков, pучейников и клопов. Встречавшийся с 1998 г. только здесь Asellus aquaticus L. с 2008 по 2010 г. отмечался также в дрейссеновых поселениях в восточном районе ВО и в подводящем канале, но с 2012 г. в ВО не обнаруживается.

Бентические двустворчатые моллюски были постоянным компонентом сообществ. В первый период поселения двустворчатых моллюсков сем. Unionidae (Unio tumidus Philipsson, U. pictorum (L.), Anodonta cygnea (L.) и A. piscinalis Nilsson) отмечали в подводящем канале на границе бетонного откоса и песчаного дна. Обычными же биотопами в ВО для крупных Bivalvia были западный, восточный и южный районы. После вселения дрейссены в ВО отмечено некоторое сокращение популяций перловицевых, особенно анодонт, несколько сократились показатели обилия двух видов p. Unio. На поверхности раковин (живых и отмерших) сформировались поселения дрейссены. В первые годы после вселения дрейссены масса ее на живых перловицах была в 1,5 раза выше, чем масса носителя, в дальнейшем это соотношение снизилось до 0,5-0,7. Осушение мелководных литоральных участков ВО ХАЭС в первую очередь отразилось на популяциях Unionidae. Так, при осушении закрытого мелководья восточного района в 2015 г. подавляющее большинство крупных моллюсков Unionidae погибло.

Исследования мелководий ВО показали, что участки выше уреза (зона заплеска) были достаточно бедны - на отдельных станциях в зообентосе отмечено 7-10 НОТ. Таксономическое богатство увеличивалось с возрастанием глубины в пределах мелководий: на участ- ках глубиной $0,4-0,8$ м зообентос был богаче (9-31 НОТ).

В сезонном аспекте значительных изменений в видовом составе не было установлено, можно лишь указать на наличие в весенне-осенний период некоторых видов личинок стрекоз, ручейников, жуков, двукрылых, не отмеченных в другие периоды (например, Ischnura elegans (van der Linden), представителей сем. Polycentropidae и Psichodidae).

Что касается роли грунтов, то минимальным количеством НОТ характеризовались сильно заиленные с большим количеством растительных остатков в северном и западном районах, а максимальным - заиленные пески восточного и южного районов. Высоким таксономическим богатством характеризовался участок впадения в охладитель р. Гнилой Рог, где щебеночный грунт и наличие постоянного течения создавали специфические нетипичные для бентали охладителя условия.

В зооперифитоне во все периоды исследования было отмечено 162 НОТ из 23 групп (до вида определено 104). Наиболее богатыми были Chironomidae (47 HOT) и Oligochaeta (37), а также Gastropoda (17), были встречены личинки Ephemeroptera и Trichoptera (по 9 НОТ), Hirudinea (8 НОТ), Odonata, Spongia (по 4 НОТ), Coleoptera, Bryozoa (по 3 НОТ), два вида дрейссенид (D. polymorpha, D. bugensis), отмечались таже Planaria torva (O.F.M.), Limnomysis benedeni Czerniavsky, Asellus aquaticus L., гидры, нематоды, ракушковые раки, клопы, клещи, мокрецы, мошки, бабочницы, львинки и др.

В первый период таксономическое богатство зооперифитона было достаточно высоким - 74 НОТ из 20 групп, от 29 до 54 НОТ в разные годы, основу богатства составляли Chironomidae (рис. 6). Таксономический со- 


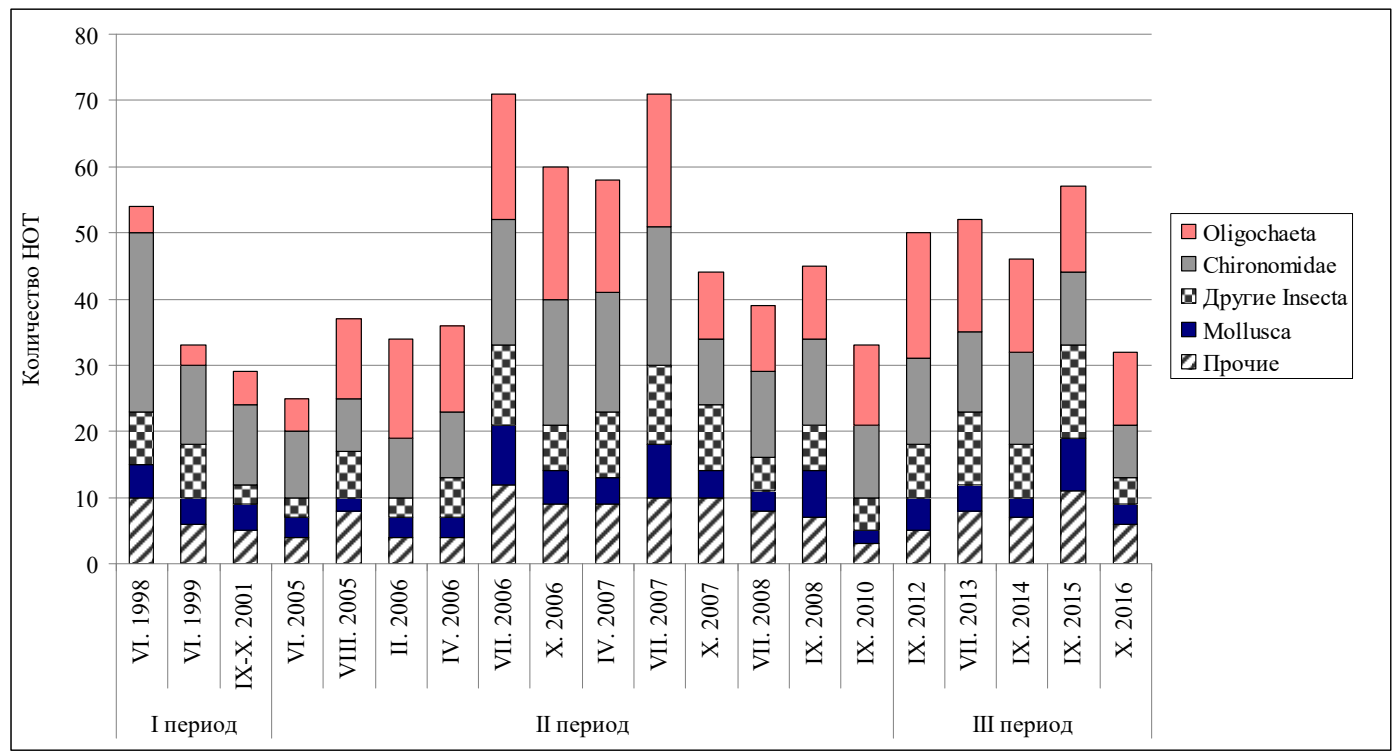

Рис. 6. Таксономическое богатство зооперифитона ВО ХАЭС; в группу «Другие Insecta» входили группы: Odonata, Ephemeroptera, Heteroptera, Coleoptera, Trichoptera, Ceratopogonidae и прочие Diptera; в группу Mollusca - Dreissena, Bivalvia, Gastrapoda; в группу «Прочие» - Spongia, Turbellaria, Nematoda, Hydra, Hirudinea, Ostracoda, Mysidaceae, Isopoda, Hydracarina, Bryozoa, а также Sisira fuscata Fabricius и Osmylus sp.

Fig. 6. Taxonomic richness of zooperiphyton of Khmelnitsky NPP cooling pond; in group «Другие Insecta» were included: Odonata, Ephemeroptera, Heteroptera, Coleoptera, Trichoptera, Ceratopogonidae, and other Diptera; in group Mollusca - Dreissena, Bivalvia, and Gastrapoda; in group «Прочие» - Spongia, Turbellaria, Nematoda, Hydra, Hirudinea, Ostracoda, Mysidaceae, Isopoda, Hydracarina, Bryozoa, Sisira fuscata Fabricius, and Osmylus sp.

став в 2001 г. несколько отличается от такового 1998-1999 гг. наличием оригинальных таксонов (11 НОТ).

Отмечено значительное возрастание богатства от первого периода ко второму до 123 НОТ, общими для этих периодов были 54 таксона. До 2008 г. большим богатством выделялась группа Chironomidae, в 2010 г. основу богатства составляли Oligochaeta. В 2006 г. исследования проводили четыре сезона, в 2007 г. - три; отбор большего количества проб в разные сезоны сказался на общем увеличении богатства за год. Наименьшие значения таксономического богатства были в конце первого и второго периодов (сначала перед вселением D. polymorpha, затем D. bugensis).
В третьем периоде (2012-2016 гг.) общий состав зооперифитона насчитывал $90 \mathrm{HOT}$ из 19 групп, наиболее богатыми были олигохеты и хирономиды (соответственно 26 и 22 НОТ). Результаты анализа сходства состава по годам показали, что первый период отличался от второго и третьего, что свидетельствует о качественных изменениях в зооперифитоне. Средние значения коэффициента сходства Серенсена для I перирода со II и III были 0,382, a между II и III - 0,556.

Состав высших водных растений. По данным исследований 2006 г. отмечено 19 видов ВВР из 11 семейств (стрелолист, рдесты сплюснутый и маленький встречались только в устье р. Гнилой Рог). Представлены виды всех экологических групп: 10 видов по- 
груженных растений, 6 - воздушно-водных (Sagittaria sagittifolia L. в зависимости от глубины, образует две экологические формы - f. tipica, f. vallisnerifolia) и три - с плавающими листьями. Один из видов рдеста (Potamogeton compressus L.) внесен в Красный список Украины как вид, находящийся под угрозой исчезновения (Техно-экосистема..., 2011). Воздушно-водные растения распространяются до глубины $0,6-0,8$ м и занимают мелководья западного, восточного и южного районов. Погруженные растения распространяются до глубины 1,5 м и занимают в среднем около 5 \% площади мелководий, они более развиты в западном и южном районах водоема.

Показатели обилия отдельных группировок гидробионтов изменялись, как и состав и структура доминирования.

В фитопланктоне максимальные значения количественных показателей $(5,84-$ 92,95 млн кл/дм ${ }^{3}$ - численность и 3,96150,21 мг/дм ${ }^{3}$ - биомасса) наблюдались в первый период исследований (рис. 7). Основная роль в формировании численности принадлежала цианобактериям и зеленым водо- рослям. В большинстве случаев доминантами были Aphanizomenon flosaquae Ralfs ex Bornet \& Flahault, Aphanocapsa incerta (Lemmer mann) G. Cronberg \& Komárek, Microcystis aeruginosa (Kützing) Kützing, Snowella lacustris (Chodat) Komárek \& Hindák, Oscillatoria planctonica Woloszynska, Aphanothece stagnina (Sprengel) A. Braun., Coelastrum microporum Nageli, Pseudopediastrum boryanum (Turpin) E. Hegewald. Состав доминантных комплексов по биомассе существенно различался во времени и пространстве. Так, в июне 1999 г. в районе выхода из отводящего канала локально наблюдалась вспышка развития Cryptomonas ovata Ehrenberg, в то время как на всей акватории доминировали зеленые или крупноклеточные представители Miozoa, такие как Ceratium hirundinella (O.F. Müller) Dujardin. $\mathrm{B}$ соответствии с классификацией оценки (Методи..., 2006) уровень количественного развития фитопланктона по его численности был в пределах от «высокий» до «очень высокий», что соответствовало 7 и 8 рангам, по биомассе - от «средний» до «очень высокий» (5-8 ранги).

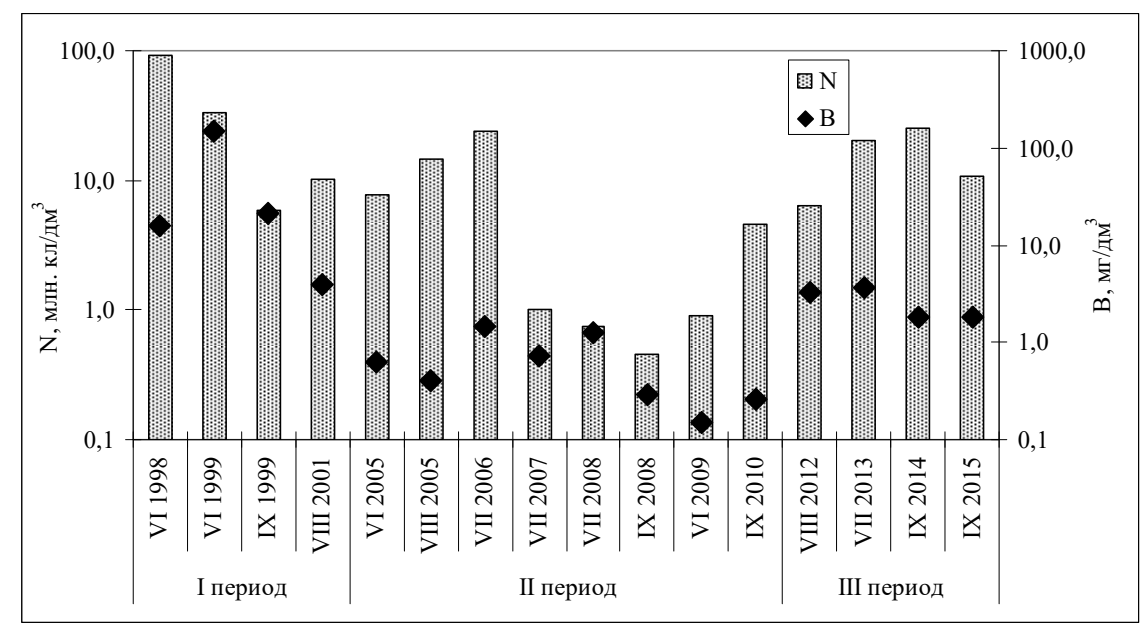

Рис. 7. Численность (N) и биомасса (В) фитопланктона ВО ХАЭС, летне-осенние периоды 1998-2015 гг.

Fig. 7. Abundance (N) and biomass (B) of phytoplankton of Khmelnitsky NPP cooling pond, summer-autumn periods of 1998-2015 
Второй период исследований характеризовался значительными колебаниями численности (от 0,46 до 23,96 млн кл/дм³) и снижением биомассы до 0,15-1,47 мг/дм³ (рис. 7). В 2005 и 2006 гг., а также в 2009 г. по численности доминировали цианобактерии, чаще всего M. aeruginosa. Биомассу в разном соотношении определяли диатомовые (в большинстве случаев Stephanodiscus hantzschii Grun., Melosira varians C. Agardh, Aulacoseira granulata (Ehrenberg) Simonsen.) и зеленые, в том числе $P$. boryanum, Monactinus simplex (Meyen) Corda, c 2009 г. также цианобактерии. В 2007-2008 гг. количественное развитие фитопланктона было минимальным за весь период исследований. В формировании численности и биомассы заметно увеличилась роль вышеозначенных диатомовых водорослей. Во второй период уровень развития фитопланктона по численности соответствовал 3-6 рангам («низкий»-«выше среднего»), по биомассе - 2-4 рангам («очень низкий» - «ниже среднего»).

В третьем периоде показатели численности изменялись в пределах 6,3525,07 млн кл/дм ${ }^{3}$, биомассы - 1,83-3,58 мг/дм ${ }^{3}$ (см. рис. 7). Наметившийся рост количественных показателей был большей частью связан с уровнем развития $M$. aeruginosa. Этот вид занимал лидирующее положение в численности фитопланктона. Уровень биомассы определяли в разном соотношении диатомовые, зеленые и цианобактерии, доля последних в общей биомассе увеличилась с 2,9 \% в 2012 г. до $36,6 \%$ в 2014 г., в 2015 г. составляла 25,8 \%. Показатель численности изменялся от «выше среднего» до «высокого» (6, 7 ранги), по биомассе - от «ниже среднего» до «среднего» $(4$, 5 ранги).

За весь период наблюдений состав доминантов в зоопланктоне варьировал незначительно. По численности преобладали ювенильные особи копепод, по биомассе крупные формы планктонных ракообразных (Daphnia longispina (O.F. Müller), Diaphanosoma brachyurum (Liévin), Eudiaptomus gracilis (G.O. Sars) и др.). Характерной чертой первого периода было присутствие в доминирующем комплексе Asplanchna sieboldi (Leydig) - крупной коловратки с тонкими покровами, которая во втором периоде выпала из состава сообщества и в дальнейшем была обнаружена только в период временного отключения энергоблоков (июль 2008 г.). Вероятно, этот вид подвержен негативному воздействию технических факторов в системах охлаждения станции, в особенности в условиях работы двух энергоблоков. В 2005 г. в состав доминирующего комплекса зоопланктона входили велигеры D. polymorpha, составляя 15,0 \% численности и 14,7 \% биомассы (Громова, Протасов, 2016).

Численность и биомасса зоопланктона непосредственно в водоеме-охладителе в период функционирования одного энергобло-

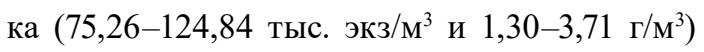
и в первые годы функционирования двух энергоблоков $\left(104,88-133,35\right.$ тыс. экз $/ \mathrm{M}^{3}$ и

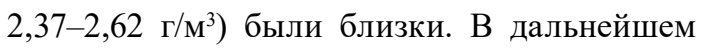
для динамики обилия зоопланктона были характерны значительные колебания. Численность и биомасса изменялись в пределах

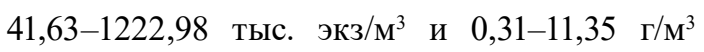
(рис. 8). Уровень количественного развития зоопланктона в первый период и в начале второго периода можно оценить рангом «ниже среднего», что соответствует мезоэвтрофному уровню. После 2007 г. уровень развития зоопланктона в разные годы изменялся от «низкого» (сентябрь 2008 г.) до «высокого» (сентябрь 2012 г.), но чаще всего был «ниже среднего» и «средним».

Обилие зоопланктона мелководных участков в 2006 и 2013 гг. было выше пелагических (численность - в 3-15 раз, биомас- 


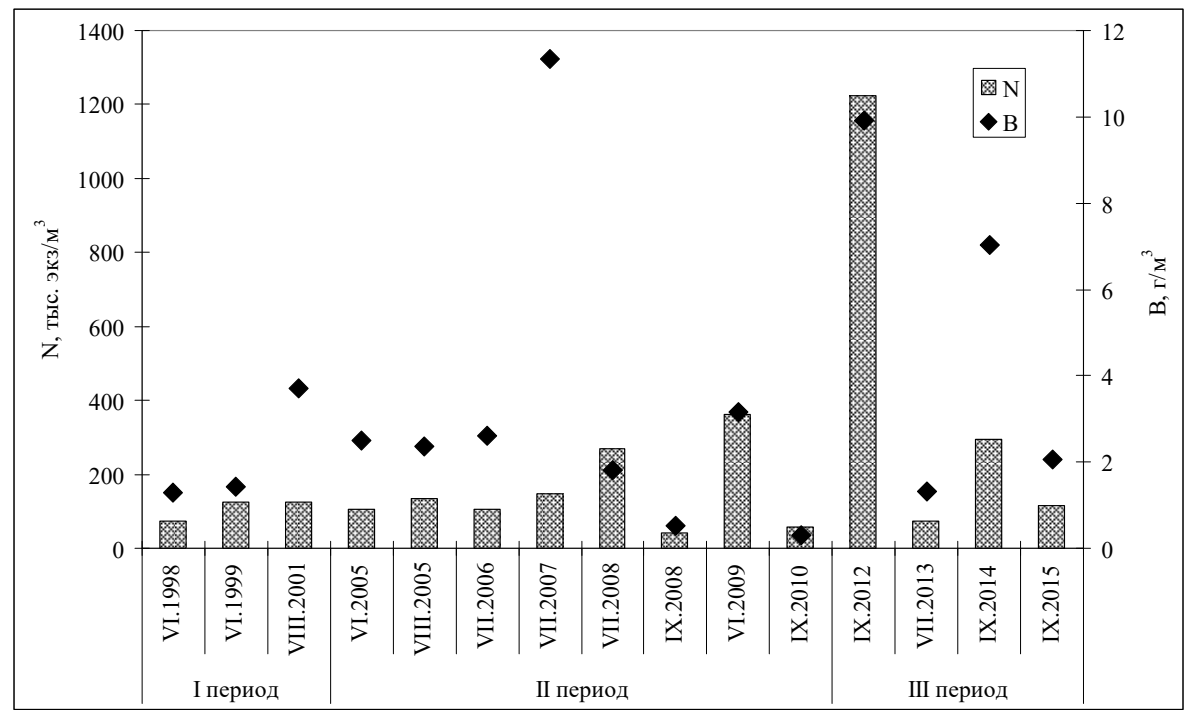

Рис. 8. Численность (N) и биомасса (В) зоопланктона ВО ХАЭС, летне-осенние периоды 1998-2015 гг.

Fig. 8. Abundance $(\mathrm{N})$ and biomass (B) of zooplankton of Khmelnitsky NPP cooling pond, summer-autumn periods of 1998-2015

са - в 2-3 раза). В 2015 г., в условиях снижения уровня воды, численность и биомасса зоопланктона на мелководьях были ниже или сходны с таковыми ближайших участков пелагиали. Средние значения численности и биомассы зоопланктона в маловодный 2015 г.

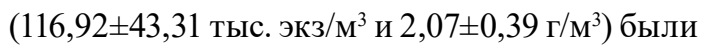
ниже пиковых значений предыдущего года в 2,5 и 3,4 раза соответственно.

За время исследований значительные изменения произошли в количественном развитии зообентоса, при этом пространственное распределение показателей численности и биомассы отличалось очень высокой мозаичностью.

В первый период численность на разных станциях в водоеме-охладителе изменялась в пределах 125-80580 экз/м², биомасса - 0,011524,62 г/м² (с учетом биомассы моллюсков сем. Unionidae), биомасса «мягкого» зообентоса достигала 64,96 г/м². По количественным показателям на большей части акватории ВО доминировали Tubificidae и Chironomidae (в основном Ch. plumosus L.). Усредненная по ВО численность в этот период не превышала

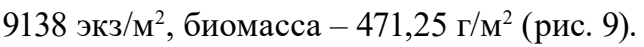

Во второй период вселившаяся D. polymorpha определила резкое возрастание количественных показателей зообентоса. Так, в 2005 г. численность возросла до 46523 экз/ м $^{2}$ (в среднем по ВО), а с учетом осевших велигеров дрейссены, которые в дальнейшем отмечались в крайне незначительных количествах, - до 109,7 тыс. экз/ $\mathbf{M}^{2}$.

Максимальная численность (в среднем по ВО) была отмечена в 2005 г., а биомасса только осенью 2006 г. Биомасса зообентоса во второй период возросла до нескольких кг/ ${ }^{2}$, максимальная, на участке впадения р. Гнилой Рог, достигала 30 кг/M², на входе в подводящий

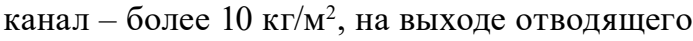
канала - более 7 кг/м². Значительной биомассой отличался зообентос подводящего канала

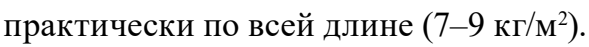

В целом по водоему основную долю в численности составляли олигохеты и дрейссена, 


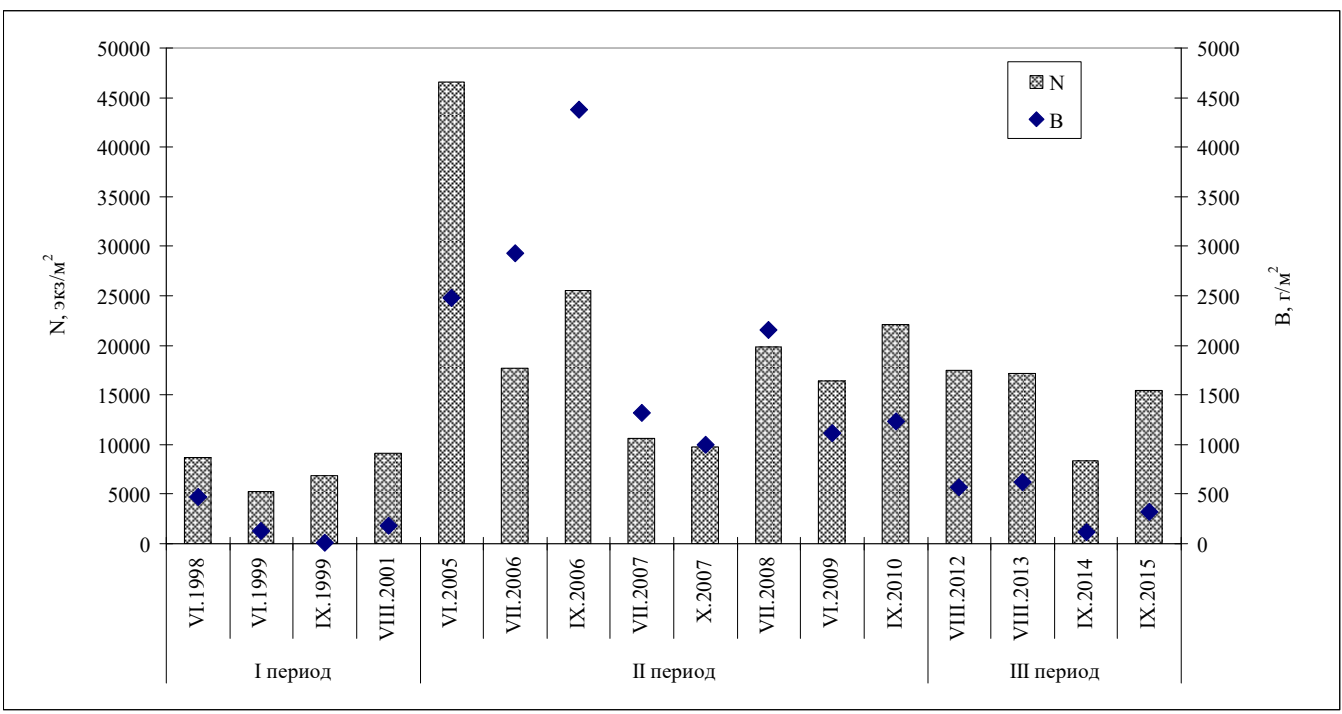

Рис. 9. Численность (N) и биомасса (В) зообентоса ВО ХАЭС, летне-осенние периоды 1998-2015 гг.

Fig. 9. Abundance $(\mathrm{N})$ and biomass (B) of zoobenthos of Khmelnitsky NPP cooling pond, summer-autumn periods of 1998-2015

а в биомассе - дрейссена и двустворчатые моллюски сем. Unionidae. Снижение уровня воды в ВО на протяжении летне-осеннего периода 2007 г. стало, вероятно, причиной временного снижения количественных показателей зообентоса, а с 2008 г. отмечено постоянное снижение численности и биомассы, вселение второго вида дрейссены мало изменило эту тенденцию. В среднем по ВО после вселения D. polymorpha биомасса зообентоса увеличилась во втором периоде в 7,2 раза относительно первого, а в третьем периоде - уменьшилась в 4,6 раза относительно второго.

Появление D. bugensis не повлияло на общую тенденцию снижения показателей обилия зообентоса в период 2012-2014 гг., а в 2015 г. отмечено некоторое возрастание численности и биомассы.

Вселение дрейссены незначительно повлияло на биомассу «мягкого» зообентоса (как вне зоны поселений дрейссены, так и в местообитаниях с поселениями дрейссены). Биомасса от первого периода $(7,35 \pm 1,11)$ не- сколько возросла ко второму $(9,85 \pm 1,50)$ и снизилась в третьем $(5,84 \pm 1,32$ г/м²). При этом максимальное обилие беспозвоночных «мягкого» зообентоса отмечено в период стабилизации развития D. polymorpha в донной подси-

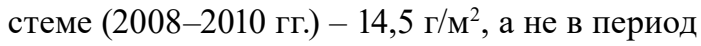
вспышки её численности (2005-2006 гг.) $5,9 \Gamma / \mathrm{M}^{2}$.

Распределение биомассы и численности зообентоса в градиенте температуры четкой зависимости не имело, однако можно отметить определенное увеличение биомассы при $25{ }^{\circ} \mathrm{C}$. В начале второго периода высокая биомасса зообентоса была характерна для подогреваемого восточного района. Показатели обилия снижались с увеличением глубины. В первый период снижение биомассы с глубиной было более выраженным, во второй и третий периоды наибольшей биомассой отличались глубины 2-5 м, исключением из этого практически во все периоды была высокая биомасса на значительных глубинах в техногенных биотопах - подводящий канал 
и выход отводящего канала, где большая глубина нивелирует влияние температуры, а значительная скорость течения обеспечивает благоприятные условия для жизнедеятельности дрейссены. Минимальная численность и биомасса зообентоса регистрировалась в северном и центральном районах (глубина соответственно 10,0 и 8,5 м).

Результаты исследований свидетельствуют, что показатели обилия зообентоса литоральной зоны выше, чем профундальной. Так, в 2014 г. численность беспозвоночных на мелководьях была практически в 4 раза, а биомасса (без учета моллюсков) - более чем в 2 раза выше, чем в профундальной зоне. Показатели обилия в зоне заплеска были низкими, увеличивались с возрастанием глубины (в пределах 0,4-0,8 м), группировкам зообентоса мелководий была свойственна полидоминантная структура.

Наименьшие показатели обилия имели сильно заиленные пески, илы с растительными остатками (северный, частично западный и центральный районы). В западном, восточном и южном районах на заиленных песках зообентос характеризовался наибольшими численностью и биомассой.

В сезонном аспекте для общей численности зообентоса отмечено увеличение в апреле, снижение - к июлю и возрастание - к октябрю (2006 г.). К лету выявлено возрастание роли олигохет и снижение - личинок хирономид, а осенью - увеличение роли дрейссены в общей численности. Биомасса устойчиво возрастала от весны к осени и максимума достигала в октябре за счет дрейссены. Биомасса «мягкого» зообентоса на протяжении вегетационного сезона 2006 г. наибольшей была в апреле и июле, при этом весной определялась в основном вкладом личинок хирономид, биомасса которых снижалась к осени из-за вылета имаго. В 2007 г. таких колебаний по сезонам не зарегистрировано, показатели обилия снижались от весны к осени.

Уровень развития зообентоса в первом и третьем периодах соответствовал рангу «средний», а развитие дрейссены во второй период определило возрастание уровня до ранга «выше среднего», что соответствует эвтрофному статусу ВО.

В первый период показатели обилия зооперифитона были невелики (рис. 10). При водолазных обследованиях гидросооружений было отмечено отсутствие заметных поселений макроформ. В подводящем канале и на плотине среди скоплений зеленых нитчатых водорослей сформировались сообщества беспозвоночных с доминированием личинок хирономид (Cricotopus silvestris Fabricius, Limnochironomus tritomus Kieffer, Glyptotendipes gripecoveni Kieffer). Численность в этих сообществах была в пределах 823 - 218333 экз/м², без учета ветвистоусых и веслоногих (Техно-экосистема..., 2011). Только в отдельных случаях возрастала до более чем 200 тыс. экз/м². Биомасса, как и численность, также была в широком диапазоне значений - от 0,45 до 383,34 г/м². Биомасса была наибольшей при доминировании губки.

В летне-осенние сезоны второго периода произошло увеличение численности в 20052006 гг. с дальнейшим снижением этого показателя к концу периода (рис. 10). При вселении дрейссены габитус и показатели обилия сообществ перифитона существенно изменились. Поясное распределение перифитона имело довольно сложную пространственную структуру (Техно-экосистема..., 2011; Протасов, Силаева, 2012), наибольшее развитие поселений дрейссены, как правило, наблюдалось на глубине 4-5 м на плотине и 5-7 м в подводящем канале. В 2006 г в сообществе с доминированием дрейссены, которое было довольно однородным практически во всех биотопах, 


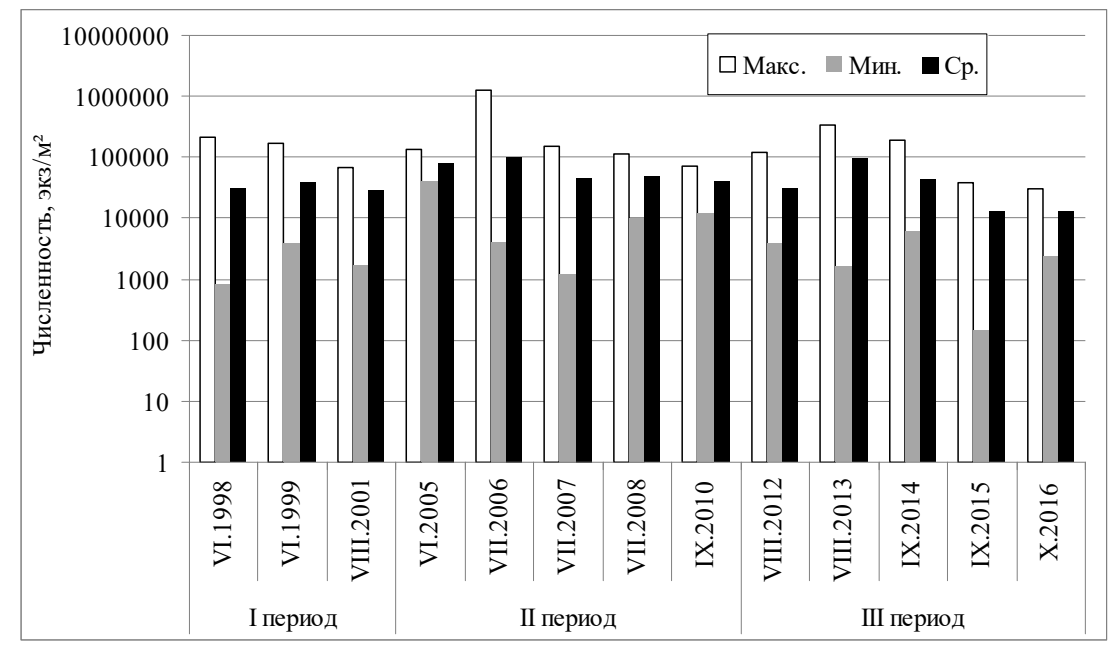

A

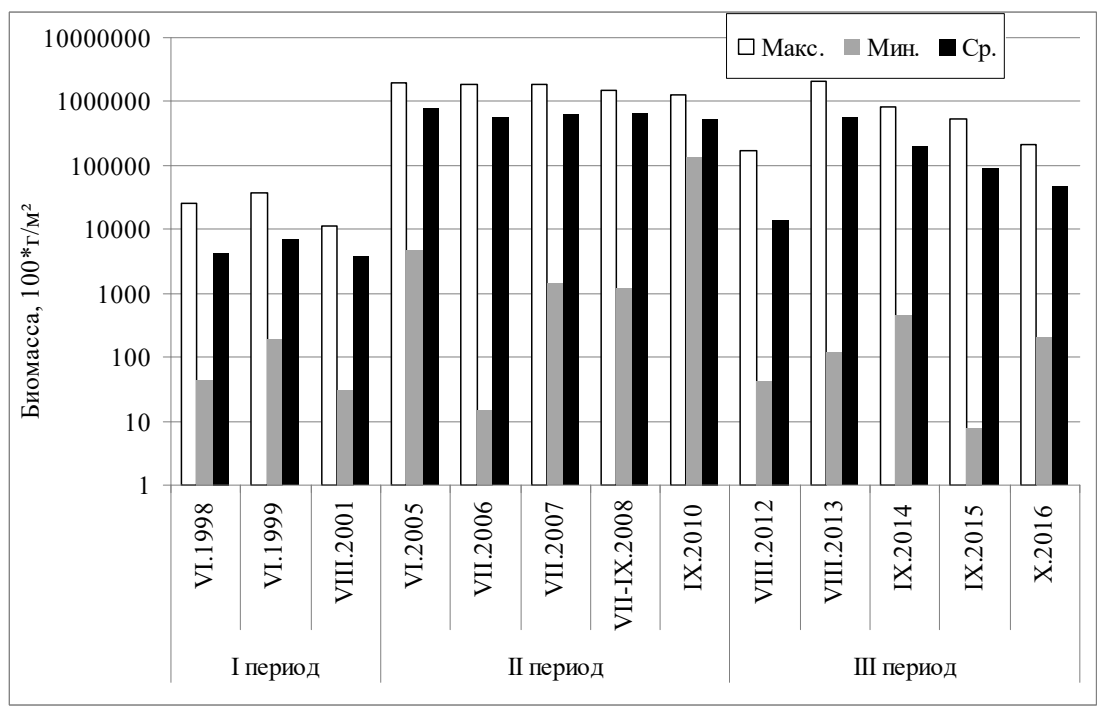

Б

Рис. 10. Численность (А) и биомасса (Б) зооперифитона ВО ХАЭС, летне-осенние периоды 1998-2016 гг. Макс. - максимальный показатель обилия; Мин. - минимальный показатель обилия; Ср. - средний показатель обилия

Fig. 10. Abundance (A) and biomass (Б) of zooperiphyton of Khmelnitsky NPP cooling pond, summer-autumn periods of 1998-2016. Макс. - maximum abundance; Мин. - minimum abundance; Сp. - mean abundance

было отмечено более 50 НОТ, численность была 74040 экз $/ \mathrm{M}^{2}$, биомасса - 10064 г/м² при средних значениях по водоему 103830 экз/ $\mathrm{M}^{2}$ и 5677,25 г/M $^{2}$ соответственно (рис. 10). О существенном доминировании дрейссены свидетельствуют низкие показатели разнообразия по биомассе - 0,015 бит/г.
Со вселением D. bugensis (третий период) к 2013 г. произошло некоторое увеличение показателей обилия перифитона. Показатели обилия в ПК в первый год третьего периода (2012 г.) изменялись с разными тенденциями. Численность снижалась с глубиной (от

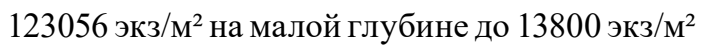


на 6,0 м), а биомасса наибольшей была на глубине 5,0 м, в основном за счет дрейссены (на $97,0 \%$ ), и несколько превышала 100 г/ $\mathrm{M}^{2}$. В подводящем канале в 2013 г. численность, в сравнении с предыдущим годом, изменилась в небольших пределах (в среднем по ПК 52275 экз $\left./ \mathrm{M}^{2}\right)$, зато биомасса возросла на порядок. Доминантом по показателям обилия, как и на плотине, была D. bugensis $(56,4 \%$ - по численности и $81,2 \%$ - по биомассе).

В отводящем канале на малых глубинах в 2012 г. по численности доминировали Specariajosinae (Vejdovsky) и Pristina aequiseta Bourne $-64,2 \%$, а по биомассе доминантом была Physa fontinalis (L.) - 73,1 \%. Состав был совершенно иным, чем в подводящем канале. На малых глубинах отводящего канала в 2013 г. показатели обилия значительно не изменились, однако произошла частичная смена доминантов: по численности доминировали Naididae sp. и P. aequiseta (59,6 \%), по биомасce - Nais sp. и Hydrophylidae sp. (61,3\%).

В 2014 г. показатели обилия начинают снижаться (см. рис. 10). Однако в отличие от остальных исследованных биотопов в ВО ХАЭС в 2014 г. в отводящем канале показатели обилия возросли на порядок. Численность составляла 110265 экз $/ \mathrm{M}^{2}$ с доминированием C. silvestris и $S$. josinae - 71,2 \%, а биомасca $-87,88 \Gamma / \mathrm{M}^{2}$ с доминированием $P$. fontinalis (84,6\%).

На плотине в 2015 г. количественные показатели снизились в сравнении с таковыми в 2013 г. и составили 10981 экз $/ \mathrm{M}^{2}$ (средняя численность по плотине) и 711,21 г/м² (средняя биомасса). Доминантами по численности на камнях были Nematoda sp. (48,1\%) и C. silvestris (11,7\%). По биомассе абсолютным доминантом была губка Ephydatia fluviatilis (L.) - 97,6 \%, а на бетоне доминировал преимущественно хирономидно-олигохетный комплекс.
В подводящем канале к 2015 г. численность беспозвоночных в среднем составляла 52275 экз $/ \mathrm{M}^{2}$ с доминированием Ostracoda sp. 19,7 \%, Ecnomus tenellus (Rambur) - 15,0 \%, D. bugensis - 14,5\%, C. silvestris - 13,3\%, a

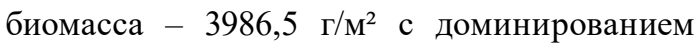
D. bugensis - 67,7\%. Средняя численность в отводящем канале в 2015 г. в сравнении с предыдущим годом снизилась на порядок и составляла 22615 экз $/ \mathrm{M}^{2}$ с доминированием Ostracoda sp. (24,1\%), Dero sp. (19,7\%) и $P$. aequiseta (16,5 \%). Биомасса же уменьшилась более чем в 5 раз $(17,10$ г/м² $)$ и произошла смена доминанта на Planorbidae sp. (72,4 \%).

В 2016 г. показатели обилия были самыми низкими в третьем периоде. Зооперифитон на плотине в приурезной зоне характеризовался низким уровнем количественных показателей с доминированием $N$. communis $(30,8 \%)$ и Hydracarina sp. (19,2 \%) от общей численности (2476 экз/м²), а по биомассе доминантом была

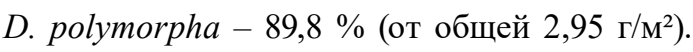
Средняя численность в ПК возросла на порядок в сравнении с предыдущим годом и составила 11713 экз $/ \mathrm{M}^{2} \mathrm{c}$ доминированием Ostracoda sp. и D. bugensis - 56,2 \%, однако биомасса на порядок снизилась до 854,00 г/M² с доминированием D. bugensis - 78,6\%.

С учетом состава зооперифитона, степени доминирования был выделен ряд сообществ (доминанты выделены по показателям деструкции), из которых наиболее распространены были сообщества, названные по доминантам: D. polymorpha; D. bugensis; $\mathrm{Ph}$. fontinalis + S. josinae; $P$. aequiseta + Hydrophylidae sp.+Nais sp.; E. carteri-последнее сообщество c доминированием Eunapius carteri (Bowerbank) (табл. 1).

В целом, в течение двух периодов после вселения дрейссенид 2005-2016 гг. в перифитоне вне зоны максимального влияния сбросов подогретых вод преобладали сообщества 
Таблица 1. Характеристики сообществ зооперифитона на неживых субстратах ВО ХАЭС за 2012-2016 гг. (среднее \pm стандартная ошибка)

Table 1. Characteristics of zooperiphyton communities on nonliving substrates of Khmelnitsky NPP cooling pond in 2012-2016 (mean \pm standard error).

\begin{tabular}{|c|c|c|c|c|c|c|}
\hline Локализация & Год & Сообщества* & $\mathrm{N}$, экз $3 / \mathrm{M}^{2}$ & $\mathrm{~B}, \Gamma / \mathrm{M}^{2}$ & 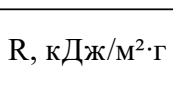 & $\begin{array}{c}\text { Кол-во } \\
\text { НОТ }\end{array}$ \\
\hline ПК+Пл $(3,0-5,5$ м) & 2012 & D. polymorpha & $18710 \pm 8840$ & $401,61 \pm 709,35$ & $0,345 \pm 0,388$ & 34 \\
\hline ОК (до 1,0 м) & 2012 & $\begin{array}{l}\mathrm{Ph} \text {. fontinalis }+\mathrm{S} \text {. } \\
\text { josinae }\end{array}$ & $29617 \pm 29751$ & $11,26 \pm 12,27$ & $0,169 \pm 0,067$ & 13 \\
\hline Пл+ПК $(3,0-8,0$ м) & 2013 & D. bugensis & $109372 \pm 95866$ & $6251,45 \pm 6445,72$ & $6,314 \pm 5,062$ & 40 \\
\hline ОК (до 1,0 м) & 2013 & $\begin{array}{l}\text { P. aequiseta }+ \\
\text { Hydrophylidae sp.+ } \\
\text { Nais sp. }\end{array}$ & $25053 \pm 7146$ & $1,51 \pm 0,49$ & $0,072 \pm 0,003$ & 11 \\
\hline ПК $(5,5$ м $)$ & 2013 & E. carteri & 1600 & 2971,52 & 13,350 & 8 \\
\hline ПК $(4,5-6,5$ м) & 2014 & D. bugensis & $24350 \pm 8446$ & $3835,43 \pm 1621,28$ & $2,176 \pm 0,839$ & 21 \\
\hline ПК+ОК (до 1,0 м) & 2014 & P. fontinalis & $93621 \pm 49617$ & $60,11 \pm 54,90$ & $0,597 \pm 0,495$ & 19 \\
\hline ПК $(4,0-6,0$ м) & 2015 & D. bugensis & $7033 \pm 2710$ & $2111,18 \pm 2733,17$ & $0,878 \pm 1,098$ & 8 \\
\hline ПК (5-7,5 м) & 2016 & D. bugensis & $16119 \pm 7951$ & $926,35 \pm 757,68$ & $0,311 \pm 0,226$ & 15 \\
\hline
\end{tabular}

Примечание: $\mathrm{N}$ - численность, В - биомасса, R - деструкция, Пл - плотина, ПК - подводящий канал, ОК - отводящий канал.

* Сообщества зооперифитона названы по доминантам по показателям деструкции.

с доминированием Dreissena. Однако если в сообществах D. polymorpha в 2006 г. биомасса

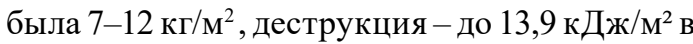

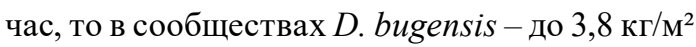
и 2,2 кДж/м². Зооперифитон в техноэкосистеме отличался достаточно высокой неоднородностью.

В течение всего периода исследований в водоеме отмечались виды-вселенцы. За период 2005-2008 гг. в ВО зарегистрированы: один ранее не отмечавшийся в пресных водах вид диатомовых водорослей (Pleurosira laevis (Ehrenberg) Compere), по одному - губок (Eunapius carteri (Bowerbank)) и кишечнополостных (Craspedacusta sowerbii (Lankester)) и моллюски трех родов (кроме дрейссены) (Theodoxus euxinus (Clessin), Ferrissia sp. Walker, Planorbella sp. Haldeman) (Sylayeva et al., 2010). В 2009 г. на откосах подводящего канала на глубине 2-4 м была выявлена зеленая нитчатая водоросль Chaetomorpha henningsii P. Richt.
В сентябре 2010 г. на выходе из сбросного канала в фитопланктоне был обнаружен новый для флоры Украины вид центрических диатомовых водорослей Cyclotella marina (Tanimura, Nagumo et Kato) AkéCastillo, Okolodk. et Ector - вид, обитающий преимущественно в морской среде (Genkal, Yarmoshenko, 2013). В этом же году на мелководьях ВО наблюдали наяду морскую (Najas marina L.), которая вызывала биопомехи в работе систем водоснабжения. В восточном районе ВО в 2009 г. был найден рогоз Лаксмана (Typha laxmannii Lepech.) (Dyachenko et al., 2012).

В сентябре 2015 г. на мелководье ВО был зарегистрирован Cylindrospermopsis raciborskii (Wolosz.) Seenayya et Subba Raju. Он выступал в качестве доминанта по численности (13,95 млн кл/дм³ 45,2 \% от общей), однако его биомасса не была значительной (1,08 мг/дм ${ }^{3}, 12,1 \%$ ) (Novoselova, Protasov, 2016). В сентябре 2016 г. C. raciborskii был об- 
наружен в одном из технических водоемов техноэкосистемы, вид характеризовался невысокими показателями обилия - 14,35 млн кл/дм ${ }^{3}$ и 1,2 мг/дм³ (0,5 и 1,4% общих показателей).

Некоторые представители планктофауны с преимущественно южным характером распространения были найдены только в отдельные годы и не играли существенной роли в структуре зоопланктона: Calanipeda aquadulcis Kritschagin (2008 г.), Diaphanosoma dubium Manuilova (2012 г.), Heterocope caspia G.O. Sars (2013 г.). На современном этапе (2015-2016 гг.) в водоем вселился и массово развивается Diaphanosoma mongolianum Ueno, заменивший аборигенный $D$. brachyurum (Liévin).

Вселившаяся (вероятно, в 2002-2003 гг.) D. polymorpha вызвала в 2004 г. в системах циркуляционного и технического водоснабжения существенные биологические помехи. Биомасcа D. polymorpha на откосах дамбы и подводящего канала в 2005 г. локально достигала 22 кг/м². Общий запас дрейссены в подводящем канале в 2006 г. составил около 630 т, на плотине - около 1530 т (Прота- сов, Силаева, 2012). В донных группировках дрейссена распространилась практически по всему водоему, отмечалась даже на значительной глубине и на илах. Особенностью летнего периода 2005 г. была высокая численность осевших велигеров (до более чем 300 тыс. экз $\left./ \mathrm{M}^{2}\right)$. В целом количественные показатели дрейссенид снижались от 2005 к 2014 г. (табл. 2). После вселения второго вида дрейссенид D. polymorpha еще преобладала в донных группировках, но с 2013 г. ее количественные показатели резко сократились и доминирование перешло к D. bugensis. Смену доминирующего вида дрейссенид можно проследить и в перифитоне (табл. 3).

Пространственное распределение поселений D. polymorpha оставалось довольно сходным в разные годы. По глубине как в подводящем канале, так и на плотине происходило возрастание биомассы дрейссены (рис. 11, 12).

Второй вид дрейссены, D. bugensis, был отмечен впервые в водоеме в 2012 г. на глубине от 3 до 6 м. Его численность и биомасса в этот год были небольшими (474 экз/ $\mathrm{M}^{2}$ и

Таблица 2. Средняя численность $\left(\mathrm{N}\right.$, экз $\left./ \mathrm{M}^{2}\right)$ и биомасса $\left(\mathrm{B}, \Gamma / \mathrm{M}^{2}\right)$ двух видов дрейссенид в донных группировках ВО ХАЭС в 2005-2016 гг.

Table 2. Average abundance $\left(\mathrm{N}, \mathrm{ind} / \mathrm{m}^{2}\right)$ and biomass $\left(\mathrm{B}, \mathrm{g} / \mathrm{m}^{2}\right)$ of two dreissenid species in benthic community of Khmelnitsky NPP cooling pond in 2005-2016

\begin{tabular}{|c|c|c|c|c|c|c|c|}
\hline \multirow{2}{*}{ Годы } & \multicolumn{2}{|c|}{ D. polymorpha } & \multirow{2}{*}{ Годы } & \multicolumn{2}{|c|}{ D. polymorpha } & \multicolumn{2}{|c|}{ D. bugensis } \\
\cline { 2 - 3 } \cline { 5 - 7 } & $\mathrm{N}$ & $\mathrm{B}$ & & $\mathrm{N}$ & $\mathrm{B}$ & $\mathrm{N}$ & $\mathrm{B}$ \\
\hline 2005 июн. & 89881 & 2043,51 & 2008 июл. & 13929 & 2557,78 & - & - \\
2006 апр. & 31530 & 2654,89 & 2009 июн. & 3028 & 1413,78 & - & - \\
2006 июл. & 14903 & 3816,98 & 2010 сент. & 5555 & 1889,09 & - & - \\
2006 окт. & 40423 & 7978,94 & 2012 сент. & 3695 & 1097,15 & 474 & 112,79 \\
2007 апр. & 11086 & 3151,58 & 2013 авг. & 87 & 7,35 & 18599 & 1970,82 \\
2007 июл. & 8442 & 1620,66 & 2014 сент. & 0,1 & $0,07 *$ & 1200 & 365,82 \\
2007 окт. & 7693 & 1660,49 & 2015 сент. & 100 & $0,18 *$ & 4867 & 3218,14 \\
& & & 2016 окт. & 50 & 1,48 & 33 & 16,59 \\
\hline
\end{tabular}

Примечание. * Обнаружены в одной пробе. 
Таблица 3. Относительные численности $(\mathrm{N})$ и биомассы (B) двух видов дрейссенид (\% от общей суммы) в перифитоне ВО ХАЭС в 2005-2016 гг.

Table 3. The percentage of D. polymorpha and D. bugensis of their total abundance (N) and biomass (B) in periphyton of Khmelnitsky NPP cooling pond in 2005-2016

\begin{tabular}{|c|c|c|c|c|c|c|c|c|}
\hline \multirow{3}{*}{ Год } & \multicolumn{4}{|c|}{ Подводящий канал } & \multicolumn{4}{|c|}{ Плотина } \\
\hline & \multicolumn{2}{|c|}{ D. polymorpha } & \multicolumn{2}{|c|}{ D. bugensis } & \multicolumn{2}{|c|}{ D. polymorpha } & \multicolumn{2}{|c|}{ D. bugensis } \\
\hline & $\% \mathrm{~N}$ & $\% \mathrm{~B}$ & $\% \mathrm{~N}$ & $\% \mathrm{~B}$ & $\% \mathrm{~N}$ & $\% \mathrm{~B}$ & $\% \mathrm{~N}$ & $\% \mathrm{~B}$ \\
\hline $2005-2010$ & 100,0 & 100,0 & - & - & 100,0 & 100,0 & - & - \\
\hline 2012 & 100,0 & 100,0 & - & - & 82,3 & 91,5 & 17,7 & 8,5 \\
\hline 2013 & - & - & 100,0 & 100,0 & 0,3 & 0,3 & 99,7 & 99,7 \\
\hline 2014 & 9,0 & 2,3 & 91,1 & 97,7 & н.д. & н.д. & н.д. & н.д. \\
\hline 2015 & 5,3 & 1,8 & 94,7 & 98,2 & - & - & 100,0 & 100,0 \\
\hline 2016 & 24,8 & 8,5 & 75,2 & 91,5 & 100,0 & 100,0 & - & - \\
\hline
\end{tabular}

Примечание. «-»- дрейссена не отмечена, н.д. - нет данных.

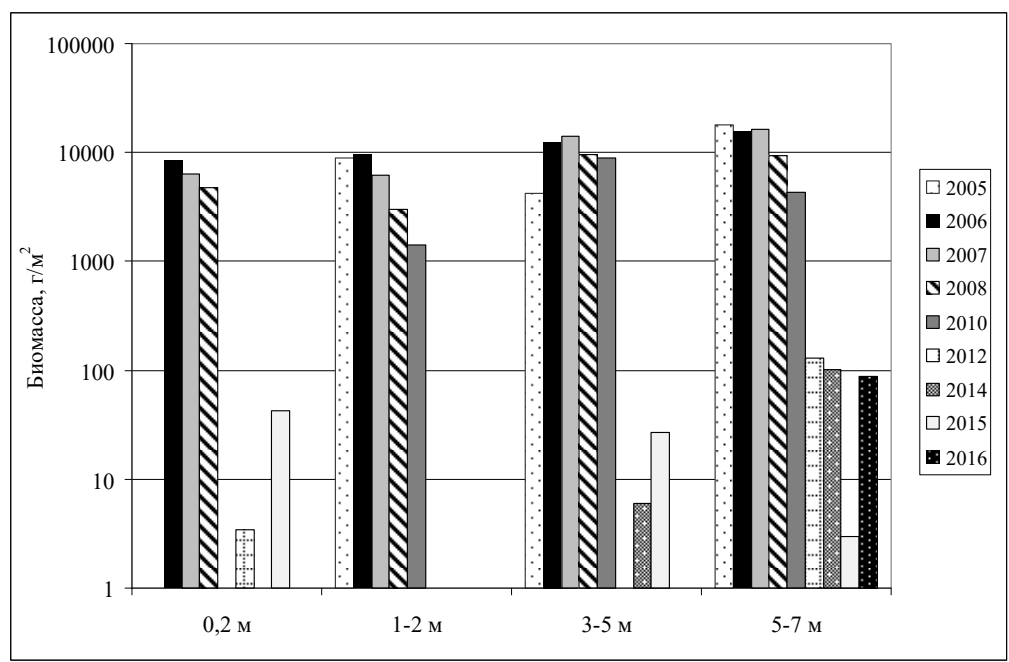

Рис. 11. Биомасса D. polymorpha на разных глубинах в подводящем канале ВО ХАЭС в 2005-2016 гг.

Fig. 11. D. polymorpha biomass at different depths in the intake channel of Khmelnitsky NPP cooling pond in 2005-1016

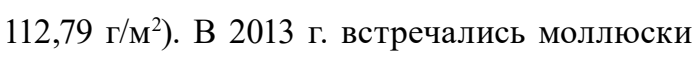
этого вида как на малой глубине (0-0,2 м) -

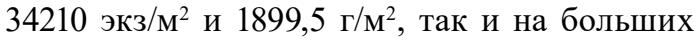
глубинах: на 3-4 м отмечены показатели

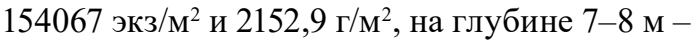
140422 экз $/ \mathrm{M}^{2}$ и 13947,4 г/ $\mathrm{M}^{2}$.

Явление контуризации. Вселение дрейссены в ВО на фоне усиления техногенной нагрузки вызвало значительное увеличение прозрачности воды, возрастание обилия контуробионтов (дрейссены, нитчатых водорослей, погруженных высших водных растений), что привело к значительным биологическим помехам в эксплуатации оборудования, связанного с водоснабжением АЭС. 


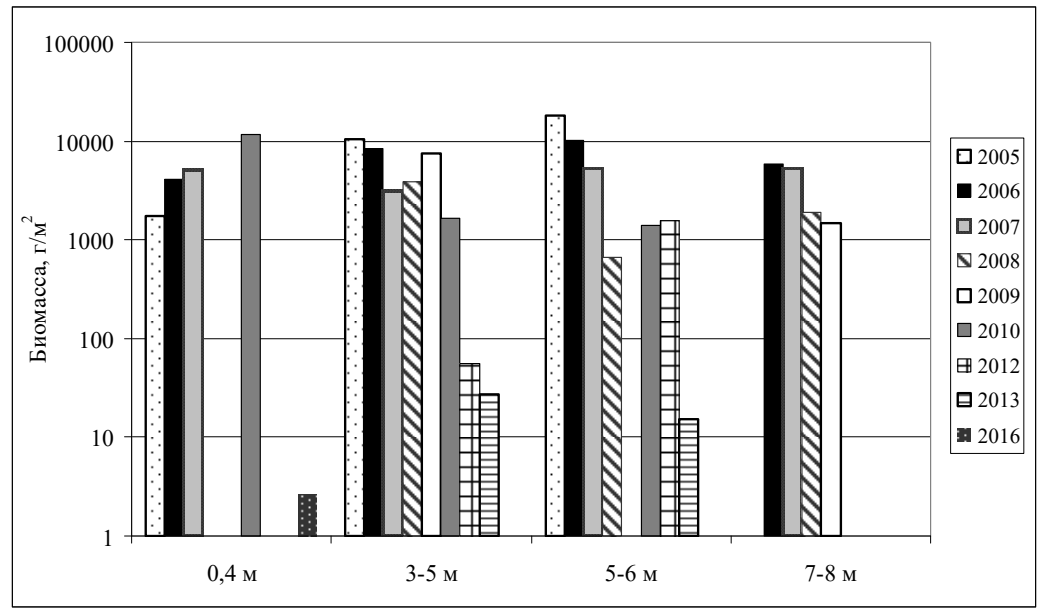

Рис. 12. Биомасса D. polymorpha на разных глубинах на плотине ВО ХАЭС в 2005-2016 гг.

Fig. 12. D. polymorpha biomass at different depths on the dam of Khmelnitsky NPP cooling pond in 2005-2016

Экологические явления в техноэкосистеме ХАЭС были сходными с теми, которые наблюдались и в других водных объектах при вселении дрейссенид (Zhu et al., 2006; Остапеня, 2007). Мы назвали этот процесс контуризацией (Protasov, 2014; Protasov, Sylaieva, 2014), что подчеркивает усиление роли в экосистеме контурных группировок (бентоса и перифитона). Кроме того, последствия этого процесса оказывают влияние на работу технического оборудования.

Оценка запаса перифитона и бентоса в первый период показала, что общий запас нитчатых зеленых водорослей во всей системе составил около 45 т (Протасов, Силаева, 2012). Собственно, на дне водоёма нитчатые водоросли существенно не развивались, а были сосредоточены на гидросооружениях. Запас беспозвоночных в бентосе был от 117 т в 1999 г. до 597 т - в 2001 г. Запас организмов зообентоса в 2006 г. возрос до 8,3 тыс. т. Еще более значительные изменения произошли в сообществах зооперифитона. Запас организмов перифитона, на $99 \%$ состоящего из дрейссены, в подводящем канале составил более 600 т. На плотине общее количество ор- ганизмов перифитона было более 1,2 тыс. т. На каменной отсыпке укрепления берега дамбы в южном районе общее количество дрейссены составляло около 10 т. Можно оценить, что в системах водоснабжения было также не менее 10 т дрейссены. Таким образом, общее количество дрейссены в техноэкосистеме в начальный период её обитания составляло 10,2 тыс. т, из которых большая часть была в бентали. Запас нитчатых водорослей в перифитали можно оценить в 142,3 т.

Внешнее поступление биогенов в ВО ХАЭС за счет сброса с очистных сооружений и со стоком реки достаточно высокое, в первый период за три года в водоем поступило 59 т фосфатов (Техно-экосистема..., 2011). Однако согласно расчетам общая экскреция фосфора дрейссеной была в 5,8 раз выше. Кроме того, следует учесть очень высокие показатели экскреции фосфора дрейссеной в обрастании технических сооружений, в частности, в подводящем канале.

Наиболее существенные следствия контуризации были отмечены в фитопланктоне: произошло значительное обеднение состава и снижение обилия. Биомасса зообентоса и пе- 
рифитона в целом возросла за счет дрейссены, но биомасса остальных организмов бентоса изменилась мало. Повышение прозрачности воды, поступление биогенов привели к бурному росту зеленых нитчатых водорослей. Они стали причиной существенных биопомех в водоснабжении АЭС. Очевидно, что произошло перераспределение процессов потребления биогенов - из пелагической в контурную подсистему.

Оценки качества водной среды. Значения категорий качества вод в техноэкосистеме ХАЭС значительно изменялись во все периоды исследований (рис. 13). При этом качество среды отводящего канала по многим показателям всегда было наихудшим - до категории 7 «очень грязные» (V класс качества вод). По некоторым показателям (например, $\mathrm{pH}$ более 8) качество среды было наихудшим только в отдельные периоды. Практически всегда индекс сапробности по показателям зообентоса в отводящем канале был наиболее высоким, что определяло качество среды (категории 5-7 - «умеренно загрязненные - очень грязные» воды).

В первый период содержание биогенных веществ в водоеме было низким - от категории 1 «очень чистые» (I класс) до категории 4 «слабо загрязненные» (III класс). В целом в первом периоде за три года (от 1998 к 2001 г.) качество несколько снизилось (средний индекс от 3,1 до 3,4) от категории 3 «достаточно чистые» до категории 3 с тенденцией перехода к категории 4 «слабо загрязненные».

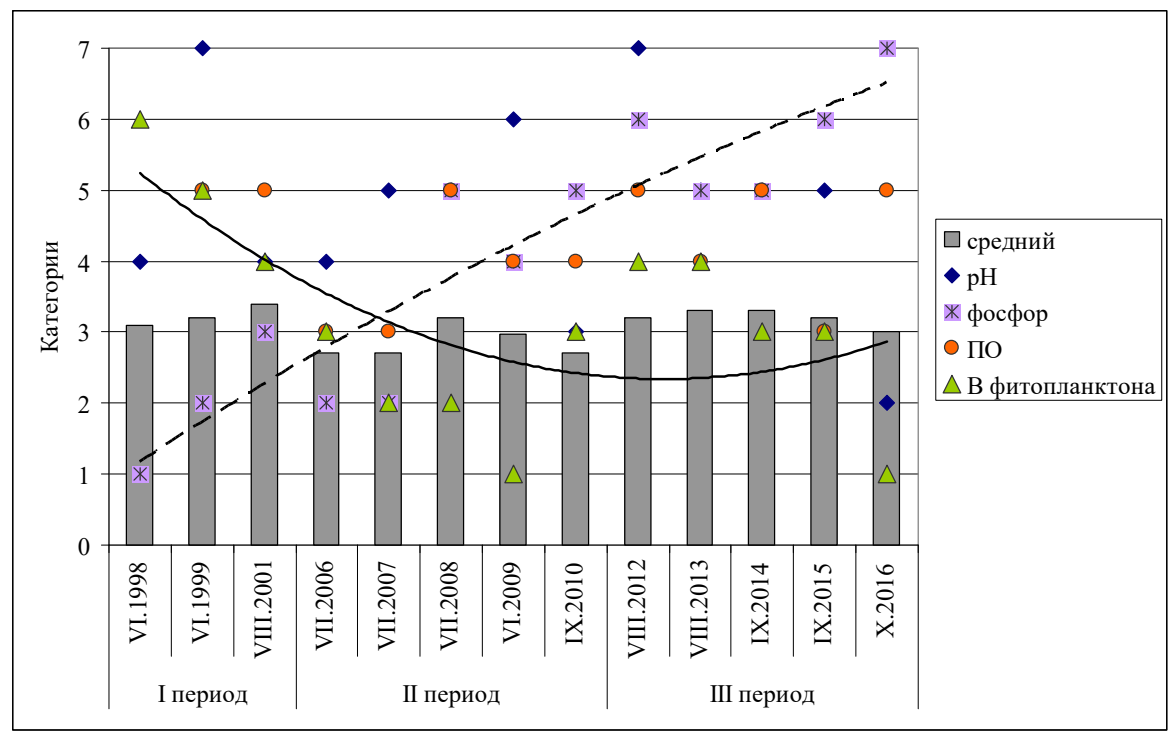

Рис. 13. Оценка качества воды ВО ХАЭС по эколого-санитарным критериям, летне-осенние периоды 1998-2016 гг. Сплошная линия - изменения значений категории «биомасса фитопланктона», пунктирная линия - изменения значений категории «содержание фосфора фосфатов». При расчете средней величины категории качества воды использованы величины следующих показателей (от 10 до 16 в разные годы), в частности: $\mathrm{pH}, \mathrm{N}-\mathrm{NH}_{4}^{+}, \mathrm{N}_{-} \mathrm{NO}_{2}^{-}, \mathrm{N}_{-} \mathrm{NO}_{3}^{-}, \mathrm{P}_{-} \mathrm{PO}_{4}^{-}$, перманганатная окисляемость, численность бактериопланктона, биомасса фитопланктона, сапробность по фитопланктону, сапробность по зообентосу

Fig. 13. Water quality assessment of Khmelnitsky NPP cooling pond based on ecological and sanitary criteria, summer-autumn periods of 1998-2016. Solid line - changes in the values of the category "phytoplankton biomass», dotted line - changes in the values of the category «phosphate phosphorus concentration». The following indicators (from 10 to 16 in different years) were used to calculate the average value of the water quality category, in particular: $\mathrm{pH}, \mathrm{N}-\mathrm{NH}_{4}{ }^{+}, \mathrm{N}_{-} \mathrm{NO}_{2}{ }^{-}, \mathrm{N}_{-} \mathrm{NO}_{3}{ }^{-}, \mathrm{P}_{-}-\mathrm{PO}_{4}^{-}$, permanganate oxidability, bacterioplankton abundance, phytoplankton biomass, phytoplankton saprobic index, zoobenthos saprobic index 
После вселения дрейссены (второй период) увеличилась прозрачность, однако в отдельные годы высоким было значение $\mathrm{pH}$ $(2008,2009)$, содержание аммонийного азота (2007 г.), фосфора фосфатов (2008, 2010), несколько улучшилось качество среды по показателям сапробности по зообентосу. Средний индекс по ВО снизился до 2,7-3,2 (в среднем 2,8), т.е. качество среды можно оценить категориями «чистые - достаточно чистые» (рис. 13).

В третий период на фоне снижения биомассы и запасов дрейссенид и, вероятно, из-за усиления техногенной нагрузки качество среды по отдельным показателям ухудшилось до категории 7 («очень грязные» воды). Так, pH был более 9 (2012 г.), возросло содержание нитритов и фосфатов (2016 г.). По среднему индексу $(3,2)$ качество среды было близким такому в первый период.

Таким образом, биотический фактор (вселение и массовое развитие мощного фильтратора), несмотря на усиление техногенной нагрузки, сыграло определяющую роль в изменении качества среды водоемаохладителя.

\section{Заключение}

В техноэкосистемах энергетических станций, где различные антропогенные факторы выражены достаточно сильно в связи с техническим назначением водоемов, особенно важной является оценка уровня и последствий техногенного влияния. Это необходимая основа для разработки мероприятий по поддержанию определенного уровня качества вод как для водопользователей, так и для природной среды. Согласно принципам Водной Рамочной Директивы ЕС для оценки состояния очень модифицированных или искусственных водных объектов рекомендовано использование понятия «экологический потенциал». Однако согласно концепции того же документа следует применять компаративные, сравнительные методики оценок. Это практически невозможно применительно к техноэкосистемам, поскольку невозможно определить «референсные», эталонные для сравнения условия. Поэтому целесообразно использование понятия «приемлемых экологических условий» (ПЭУ) (Protasov et al., 2016), с которыми и происходит сравнение реальной ситуации. Для ПЭУ целесообразно использовать показатели качества среды, категории трофности, которые определяются по комплексу показателей: количественному развитию гидробионтов, гидрохимическим и гидрофизическим показателям (Методика..., 1998). Так, при подготовке материалов для ТЭО спуска водоема-охладителя Чернобыльской АЭС нами был предложен в качестве ПЭУ комплекс показателей, соответствующий мезоэвтрофным - эвтрофным условиям (Силаєва, Протасов, 2016).

Что касается важности биотических факторов в жизни техноэкосистем, то многолетние наблюдения показали, что вселение дрейссенид оказало сопоставимое или даже большее воздействие на экосистему, чем техногенные факторы. Развитие популяции мощного фильтратора привело к явлению контуризации, то есть к существенному сдвигу основных продукционнодеструкционных процессов из пелагической части в контурные подсистемы, в сообщества бентоса и перифитона, то есть в контурные группировки (Протасов, Силаева, 21012). В этот период отмечались значительные биологические помехи в работе оборудования АЭС. 


\section{Список литературы}

Баканов А.И. (1997) Использование характеристик разнообразия зообентоса для мониторинга состояния пресноводных экосистем. Мониторинг биоразнообразия. М., с. 278-282 [Bakanov A.I. (1997) Use of characteristics of zoobenthos diversity for monitoring of the status of freshwater ecosystems. Monitoring of biodiversity. Moscow, p. 278-282 (in Russian)]

Громова Ю.Ф., Протасов А.А. (2016) Многолетняя динамика и распределение велигеров Dreissena в водоеме-охладителе Хмельницкой АЭС и их роль в структуре зоопланктона. Гидробиологический журнал, 52(5): 3-17 [Gromova Yu.F., Protasov A.A. (2016) Multiyear dynamics and distribution of Dreissena veligers in the cooling pond of Khmelnitsky NPP and their role in the structure of zooplankton. Hydrobiological Journal [Gidrobiologicheskiy zhurnal], 52(5): 3-17 (in Russian)]

Животова Е.Н. (2007) Использование зоопланктона в биоиндикации теплового загрязнения водоемов-охладителей АЭС. Вестник ВГУ. Серия: Химия. Биология. Фармаџия, 1: 73-75 [Zhivotova E.N. (2007) Using of zooplankton in bioindication of thermal pollution of NPP cooling ponds. Proceedings of Voronezh State University. Series: Chemistry. Biology. Pharmacy [Vestnik VGU. Seria: Himiya. Biologiya. Farmatsiya], 1: 73-75 (in Russian)]

Методи гідробіологічних досліджень поверхневих вод (2006) Київ, Логос, 408 с. [Methods of hydrobiological studies of surface waters (2006) Kyiv, Logos, 408 p. (in Ukrainian)]

Методика екологічної оцінки якості поверхневих вод за відповідними категоріями (1998) Київ, Символ-Т, 28 c. [Methods of environmental assessment of surface water quality by the respective categories (1998) Kyiv, Symvol-T, 28 p. (in Ukrainian)]

Мониторинг, использование и управление водными ресурсами бассейна р. Припять (2003) Минск, Белсэнс, 269 с. [Monitoring, use and management of water resources of river Pripyat basin (2003) Minsk, Belsens, 269 p. (in Russian)]

Остапеня А.П. (2007) Деэвтрофикация или бентификация? Материаль III Междунар. науч. конф. «Озерные экосистемы: биологические прочессы, антропогенная трансформация, качество водыр. Минск, БГУ, с. 31-32 [Ostapenya A.P. (2007) Deeutrophication or bentification? Materials of the III International Scientific Conference «Lake ecosystems: biological processes, anthropogenic transformation, water quality». Minsk, BGU, p. 31-32 (in Russian)]

Протасов А.А., Новоселова Т.Н. (2015) Взаимосвязь между показателями прозрачности воды и развитием водорослей планктона в водоеме-охладителе Хмельницкой АЭС. Ядерна енергетика та довкілля, 1 (5): 50-52 [Protasov A.A., Novosolova T.N. (2015) Correlation between indicators of water transparency and the development of plankton algae in the cooling pond of Khmelnitsky NPP. Nuclear power and the environment [Yaderna energetyka ta dovkilla], 1 (5): 50-52 (in Russian)]

Протасов А.А., Силаева А.А. (2012) Контурные группировки гидробионтов в техноэкосистемах ТЭС и АЭС. Киев, 274 с. [Protasov A.A., Silaeva A.A. (2012) Contour communities of hydrobionts in techno-ecosystems of TPP and NPP. Kiev, 274 p. (in Russian)]

Силаєва А., Протасов О. (2016) Довгострокові зміни у контурних угрупованнях водоймиохолоджувача Чорнобильської АЕС. The scientific proceedings of the International network AgroBioNet «Biodiversity after the Chernobyl accident». Part II. Nitra, Slovak University of Agriculture, p. 211-214 [Sylayeva A., Protasov O. (2016) Long-term changes of contour communities

$$
-483-
$$


in cooling pond of Chernobyl NPP. The scientific proceedings of the International network AgroBioNet «Biodiversity after the Chernobyl accident». Part II. Nitra, Slovak University of Agriculture, p. 211214 (in Ukrainian)]

Техно-экосистема АЭС. Гидробиология, абиотические факторы, экологические оценки (2011) Киев, 234 с. [Techno-ecosystem of the nuclear power plant. Hydrobiology, abiotic factors, ecological estimations (2011) Kiev, 234 p. (in Russian)]

Dyachenko T.N., Silayeva A.A., Yarmoshenko L.P. (2012) First records of some species of macrophytes in the cooling pond of the Khmelnitskiy NPS. Hydrobiological Journal, 48 (2): 16-20

Genkal S.I., Yarmoshenko L.P. (2013) Centric diatoms (Bacillariophyta) of the cooling pond of the Khmelnitskiy nuclear power station (Ukraine). Hydrobiological Journal, 49 (1): 51-63

Novoselova T.N., Protasov A.A. (2016) Findings of cyanobacteria of tropical and subtropical origin in technoecosystems of NPP and TPP of Ukraine. Hydrobiological Journal, 52 (6): 103-107

Pashkova O.V. (2010) Zooplankton of the cooling pond of the Chernobyl NPP prior and after its removal from service. Hydrobiological Journal, 46 (1): 27-40

Protasov A.A. (2006) Communities of invertebrates of the cooling pond of the Chernobyl nuclear power station. Report 1. Communities of zooplankton, their composition and structure. Hydrobiological Journal, 42 (1): 3-21

Protasov A.A. (2014) Conceptual models of the contourization processes in the aquatic ecosystems. Hydrobiological Journal, 50 (1): 3-19

Protasov A.A. (2014a) Concept of techno-ecosystem in technical hydrobiology. Hydrobiological Journal, 50 (5): 3-15

Protasov A.A., Panasenko G.A., Babariga S.P. (2009) Biological hindrances in power stations exploitation, their typization and main hydrobiological principles of control. Hydrobiological Journal, 45 (1): $32-45$

Protasov A.A., Zubkova Ye.I., Silayeva A.A. (2016) Conceptual approaches to organization of hydrobiological monitoring of techno-ecosystems of thermal and nuclear power plants. Hydrobiological Journal, 52 (2): 59-70

Protasov A.A., Sylaieva A.A. (2014) Contourization and its features in technoecosystems. Inland Water Biology, 7 (2): 101-107

Sylayeva A.A., Protasov A.A., Yarmoshenko L.P., Babariga S.P. (2010) Invasive species of algae and invertebrates in the Cooling Pond of the Khmelnitskiy NPP. Hydrobiological Journal, 46 (2): $13-21$

Zhu B., Fitzgerald D.G., Mayer C.M., Rudstam L.G., Mills E.L. (2006) Alteration of ecosystem function by zebra mussels in Oneida Lake: impacts on submerged macrophytes. Ecosystems, 9: 10171028 